\title{
Effectiveness and cost-effectiveness of home-based postpartum care on neonatal mortality and exclusive breastfeeding practice in low-and-middle-income countries: a systematic review and meta- analysis
}

\author{
Gizachew Tadele Tiruneh $^{1 *}$ D, Chalachew Bekele Shiferaw ${ }^{2}$ and Alemayehu Worku ${ }^{3}$
}

\begin{abstract}
Background: Early postpartum facility discharge negatively impacts mothers' proper and effective use postnatal care. Cognizant of these facts, home-based postnatal care practices have been promoted to complement facilitybased care to reduce neonatal mortality. This systematic review evaluated the effectiveness and cost-effectiveness of home-based postnatal care on exclusive breastfeeding practice and neonatal mortality in low-and-middleincome countries.

Methods: Randomized trials and quasi-experimental studies were searched from electronic databases including PubMed, Popline, Cochrane Central Register of Controlled Trials and National Health Service Economic Evaluation databases. Random-effects meta-analysis model was used to pool the estimates of the outcomes accounting for the variability among studies.

Results: We identified 14 trials implementing intervention packages that included preventive and promotive newborn care services, home-based treatment for sick neonates, and community mobilization activities. The pooled analysis indicates that home-based postpartum care reduced neonatal mortally by $24 \%$ (risk ratio $0.76 ; 95 \%$ confidence interval $0.62-0.92 ; 9$ trials; $n=93,083$; heterogeneity $p<.01$ ) with no evidence of publication bias (Egger's test: Coef. $=-1.263 ; p=.130$ ). The subgroup analysis suggested that frequent home visits, home visits by community health workers, and community mobilization efforts with home visits, to had better neonatal survival. Likewise, the odds of mothers who exclusively breastfed from the home visit group were about three times higher than the mothers who were in the routine care group (odds ratio: 2.88; 95\% confidence interval: 1.57-5.29; 6 trials; $n=20,624$ mothers; heterogeneity $p<.01$ ), with low possibility of publication bias (Coef. $=-7.870 ; p=.164$ ). According to the World Health Organization's Choosing Interventions that are Cost-Effective project recommendations, home-based neonatal care strategy was found to be cost-effective.

(Continued on next page)
\end{abstract}

\footnotetext{
* Correspondence: gizt121@gmail.com

${ }^{1}$ The Last Ten Kilometers (L1OK) Project, JSI Research \& Training Institute, Inc.,

Addis Ababa, Ethiopia

Full list of author information is available at the end of the article
}

(c) The Author(s). 2019 Open Access This article is distributed under the terms of the Creative Commons Attribution 4.0 International License (http://creativecommons.org/licenses/by/4.0/), which permits unrestricted use, distribution, and reproduction in any medium, provided you give appropriate credit to the original author(s) and the source, provide a link to the Creative Commons license, and indicate if changes were made. The Creative Commons Public Domain Dedication waiver (http://creativecommons.org/publicdomain/zero/1.0/) applies to the data made available in this article, unless otherwise stated. 
(Continued from previous page)

Conclusions: Home visits and community mobilization activities to promote neonatal care practices by community health workers is associated with reduced neonatal mortality, increased practice of exclusive breastfeeding, and cost-effective in improving newborn health outcomes for low-and-middle-income countries. However, a welldesigned evaluation study is required to formulate the optimal package and optimal timing of home visits to standardize home-based postnatal interventions.

Keywords: Cost, Cost-effectiveness, Exclusive breastfeeding, Home visit, Home-based postnatal care, Home-based newborn care, Low-and-middle-income countries, Neonatal mortality, Postpartum home visit,

\section{Background}

Globally, about three-quarters of neonatal deaths occur during the first week of life, of which about half occur in the home [1]. More than half of all neonatal deaths could be averted with care being provided during the postpartum period (i.e., 30\% of all neonatal deaths can be averted with care of small and ill neonates, $12 \%$ with care of healthy neonates, and $10 \%$ with immediate newborn care) [2]. A wealth of evidence exists on a range of cost-effective life-saving maternal and newborn health $(\mathrm{MNH})$ interventions essential to end preventable maternal and neonatal deaths [2, 3]. But, in low-and-middleincome countries (LMICs), access to evidence-based high impact interventions improving maternal and neonatal mortality is often low [4-6].

Despite the critical importance of the postnatal period to promote optimal essential neonatal care practices as well as to save the lives of neonates [2], many women and their newborns do not have access to health care during the early postnatal period. This puts both the women and their newborns at an increased risk of morbidity and mortality [7]. Furthermore, due to cultural practices, mothers and newborns spend most of the postnatal period in the home regardless of place of birth [8]. Early postpartum discharge from facility is another factor that contributes to the lack of proper postnatal care (PNC) use $[9,10]$.

Cognizant of these facts, providing home-based postpartum care is crucial to reach mothers and newborns [9]. As a result, home-based postnatal care practices have been promoted to complement facility-based care to improve early postpartum $\mathrm{MNH}$ care as well as to reduce neonatal mortality $[11,12]$.

Evidence in developing countries shows that communitybased postpartum interventions are effective in improving MNH service use [3, 12-17]. However, there is limited evidence of the effectiveness as well as cost-effectiveness of home-based postpartum care strategy [18] and it is also an area where there is a critical knowledge gap, globally [19].

Thus, this systematic review evaluated the effectiveness and cost-effectiveness of home-based PNC on exclusive breastfeeding practice and neonatal mortality in LMICs.

\section{Methods}

Researchers determined the review methods in advance and we registered the protocol on the International Prospective Register of Systematic Reviews (PROSPERO) (registration number: CRD42018106006).

\section{Inclusion and exclusion criteria}

Randomized trials and quasi-experimental studies that report effectiveness or cost-effectiveness of postpartum home-based interventions on practice of exclusive breastfeeding and neonatal mortality or economic evaluation studies that compared home-based interventions with routine care were included. Articles written in the English language, with no publication date restriction to get adequate studies and interventions implemented in LMIC were considered for this study.

Citations without abstracts and/or full text, commentaries, letters, duplicate studies and editorials, studies written by different languages other than English were excluded from the review. Additionally, studies were excluded if it, 1) did not report on postpartum home visit, newborn mortality, exclusive breastfeeding, or cost, 2) did not have comparator, and 3) were not done in LMIC setting.

\section{Search strategy}

The research team searched peer-reviewed journal articles from electronic databases including PubMed, Popline, ClinicalTrials.gov, Cochrane Central Register of Controlled Trials and National Health Service (NHS) Economic Evaluation databases. For more articles, reference lists of the initial search were also checked.

First, we identified concepts including 1) effectiveness or cost-effectiveness, 2) postpartum care or neonatal care, and 3) LMICs using the PICO review acronymPopulation, Intervention, Comparison, and Outcome. Then for each concept, search terms (including synonyms and $\mathrm{MeSH}$ terms) were identified and used in a variety of combinations for these concepts. For database search, combination of the following keywords were used "(postnatal care OR postpartum OR puerper" OR post partum OR post natal OR neonatal OR newborn) 
AND (home visit OR home care OR facilit* OR hospital care $O R$ health center care OR facility based care OR home care service*) AND (infant mortality OR neonatal mortality) OR (breastfeeding OR exclusive breastfeeding) $O R$ (cost benefit analysis $O R$ cost analysis $O R$ efficien* OR health care cost OR economic evaluation OR cost effectiveness OR impact OR effect*))". A search strategy for PubMed, Popline, Cochrane Central Register of Controlled Trials and NHS Economic Evaluation databases are included in the additional file (Additional file 1). ClinicalTrials.gov was searched for recently completed trials.

\section{Definition of terms}

\section{Intervention}

Interventions-including counseling; examination and management; and provision of services-provided to women and newborns in the first six weeks after birth at home by health providers or community health workers.

Any home visit innovations, initiatives, approaches, or activities carried out during the postnatal period, with the aim of either providing maternal and newborn health service or influencing maternal and newborn careseeking behavior and practices, including home-based treatment for illness, community mobilization efforts, and any home-based/community-based neonatal interventions, were considered as home-based postnatal care.

\section{Comparison}

Routine postnatal care provided to mothers who delivered in a health facility on discharge or care provided after discharge within six weeks when the women visited the facility. Usually, in LMICs, PNC is provided on discharge after facility delivery within $6 \mathrm{~h}$ and when the women visited the facility for family planning or immunization services after discharge within six weeks.

\section{Settings}

Low-and-Middle-Income Countries are countries with a gross domestic product (GDP) per capita of less than US $\$ 4655$ as categorized by the World Bank in 2017. The list of countries is included in the additional file (Additional file 1).

\section{Outcomes}

The definitions for the outcome variables - neonatal mortality, exclusive breastfeeding, and cost-effectiveness-are given below.

Neonatal mortality: neonates who died within the first 28 days of life.

Exclusive breastfeeding: women who exclusively breastfed their child as per the age of the neonate determined by each study at the time of the survey.
Cost-effectiveness: Cost per effect as measured by the cost per home visit, per life-saved (or death averted), per life-year saved (or years of life lost averted), or per disability-adjusted life-year (DALY) averted.

The cost results reported in non-US dollars (USD) were converted to USD and inflated to 2016 prices $[20,21]$. The GDP per capita was used as a benchmark to consider against the cost-effectiveness of the intervention. For this purpose, the 2016 country's USD prices were used [21]. World Health Organization (WHO) considers strategies and interventions to be cost-effective if the cost per DALY averted is less than three times the GDP per capita and highly costeffective if less than the GDP per capita [22].

\section{Selection and management of results}

The search returned 1081 records after removing duplicates. Endnote reference manager was used to upload search results and create library of all search results for the purpose. Two review authors (GT and CB) independently screened the titles and abstracts yielded by the search against the inclusion criteria. We obtained full reports for all titles that appear to meet the inclusion criteria. Discrepancies between reviewers regarding the decision of inclusion were resolved through discussions.

During the title and abstract review stage, publications were excluded based on the exclusion criteria. Additionally, at the full-text review stage, publications were excluded if it did not report on our outcome measures and presented secondary rather than primary analysis (in which case the references were checked for more articles for inclusion).

Accordingly, 42 full articles were identified from screening titles and abstracts. The final synthesis was based on 14 journal articles. The results of the search and the process of screening and selecting studies for inclusion are illustrated using the study flow diagram seen below (Fig. 1).

\section{Quality assessment}

The risk of bias of each included study was assessed using the Cochrane Collaboration criteria: sequence generation, allocation concealment, blinding of participants and personnel, blinding of outcome assessment, incomplete data, selective reporting and other biases [23]. Through discussion, researchers evaluated the possible risk of bias of each of the six domains from the extracted information and rated as high risk, low risk or unclear, if there was insufficient detail reported in the study, based on the criteria for judging the risk of bias. Graphic representations of risk of bias within and across studies were computed using Review Manager Software v5.3 (RevMan) software [23, 24]. 


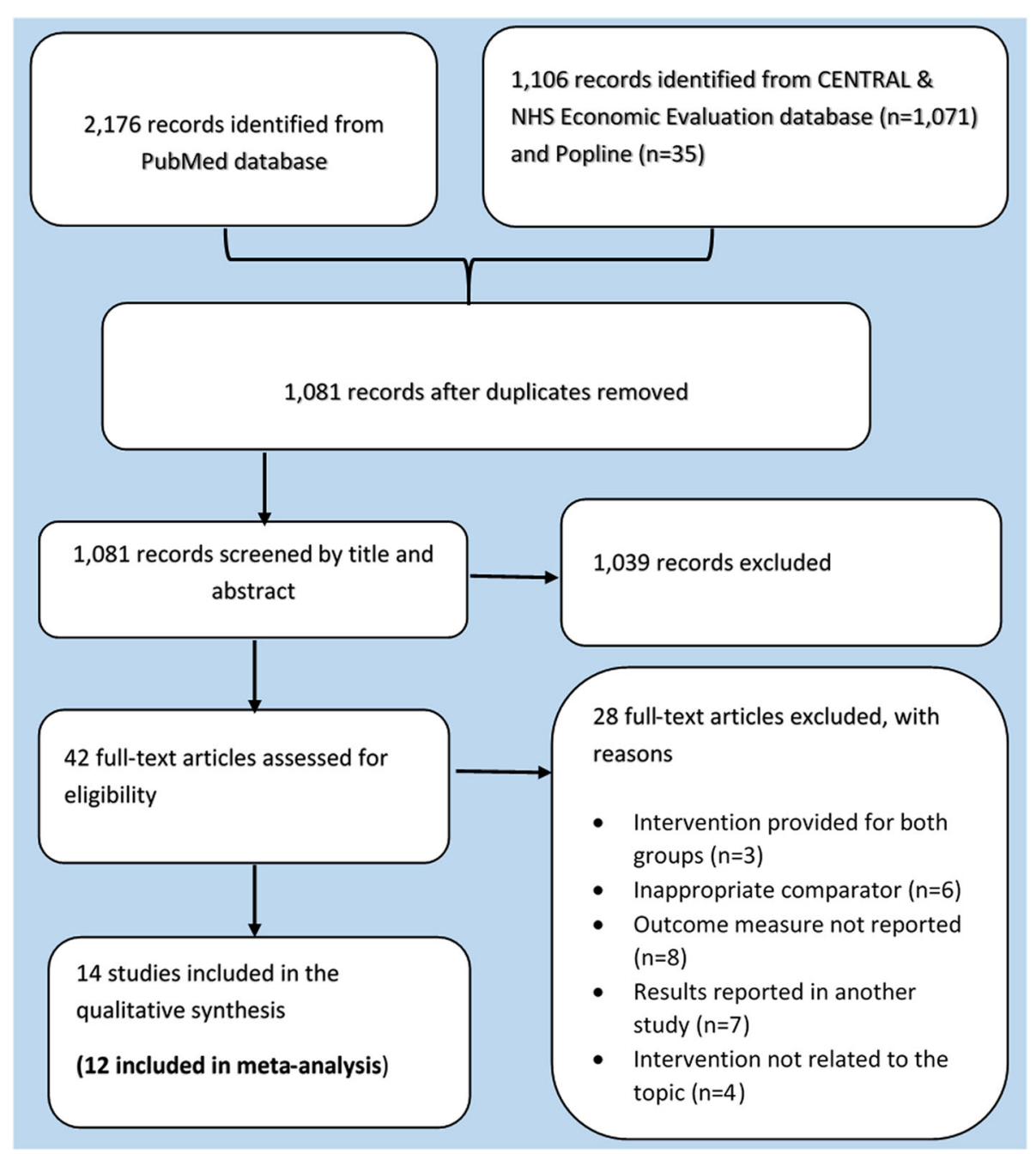

Fig. 1 Study flow diagram

In cluster-randomized trials, allocation concealment was treated as low risk if trials randomized all clusters at once though it lacked concealment of an allocation sequence [23]. In addition, recruitment bias, contamination bias, baseline imbalance, loss of clusters, and lost to follow-up were considered in the analysis of the risk of bias in cluster-randomized trials.

The quality of the evidence pertaining to the outcomes was graded using the Grading of Recommendations Assessment, Development and Evaluation (GRADE) approach based on study limitations, consistency of effect, imprecision of effect estimates, indirectness of evidence and potential publication bias [23]. Researchers jointly evaluated the quality of the evidence for each outcome through discussion and a Summary Findings table was produced using GRADEPro software [25].

Standard reporting checklists-Preferred Reporting Items for Systematic and Meta-Analysis (PRISMA) for systematic review and meta-analysis and International
Society for Pharmacoeconomics and Outcomes Research (ISPOR) for the trial-based cost-effectiveness analysiswere followed to establish minimum information that should be included when reporting.

The quality of the trial-based cost-effectiveness studies was assessed based on the core items recommended for conducting economic analyses alongside clinical trials [26]. Each study was given a 1-point score for each item fully met, 0.5 for partially met, and 0 for none. Then, trials that scored $75 \%$ or more were categorized as high quality, trials scored between 50 and $74 \%$ were ranked as medium, and studies scored less than 50\% scores were rated as poor.

\section{Data extraction}

The first reviewer (GT) completed the data extraction form for all studies using RevMan software [23, 24], and the second reviewer $(\mathrm{CB})$ assessed the accuracy of the extracted data. Differences were resolved through discussions. 
For those cluster-randomized trials where the analysis did not properly account for cluster design or did not have sufficient information regarding proper accounting of cluster design, we extracted the data after correcting the analysis to reduce the size of each trial to its effective sample size as described in the Cochrane Handbook [23]. The effective sample size of a single intervention group in a cluster-randomized trial is its original sample size divided by the design effect. The design effect is given by.

$$
1+(M-1) I C C
$$

where $M$ is the average cluster size and ICC is the intra-cluster correlation coefficient.

We used an estimate of 0.02 ICC derived from the previous trials [27-32].

We identified a trial [33] which included more than two arms. As such, we combined the groups using the methods described in the Cochrane Handbook [23] to analyze them.

\section{Data synthesis}

Descriptive information about the eligible studies was summarized using text and Tables. A narrative synthesis was used to analyze and interpret the findings.

Random-effects meta-analysis model [23, 34] was used to pool the estimates of the outcomes, accounting for the variability among studies using Stata v15 [35]. Both single and multiple level meta-regression analysis was done to identify the independent predictor variables for the outcome of interest.

The results were presented as risk ratio (RR) \& odds ratio (OR) with 95\% confidence intervals and the estimates of $\mathrm{Tau}^{2}$ and $\mathrm{I}^{2}$ statistic for heterogeneity. We also investigated the presence of publication and other bias in the extracted data using funnel plot and Stata's "metabias" command [34, 35].

However, meta-analysis was not appropriate for the cost-effectiveness outcomes as the analytic approaches were different among trials which makes it difficult to combine the outcomes together.

\section{Assessment of heterogeneity}

The $P$-value of the Chi-squared test of heterogeneity and the $\mathrm{I}^{2}$ and $\mathrm{Tau}^{2}$ statistics were examined for heterogeneity between the trials to judge whether there were any apparent differences in the direction or size of the treatment effect between studies. The thresholds for the presence of heterogeneity among the trials were determined if the value of $\mathrm{I}^{2}$ was greater than $30 \%$, and the value of $\mathrm{Tau}^{2}$ was greater than zero or the $P$-value of the $\mathrm{Chi}^{2}$ test for heterogeneity was greater than 0.1 .

\section{Subgroup analysis}

We undertook subgroup analysis to examine the effect of home visit on neonatal mortality varied by 1) number or frequency of PNC visits ( $\leq 3$ vs. $>3$ visits), 2 ) coverage of $\mathrm{PNC}$ visits made to the mother and/or newborn that is proportion of neonates and/mothers receiving a postnatal visit in the intervention areas/clusters) ( $\leq 70 \%$ vs. $>70 \%)$, 3 ) type of care (preventive interventions vs preventive and curative interventions, 4) type of health worker (health professionals vs. community health workers (CHWs)), 5) intervention components (community mobilization efforts and home visits vs. home visits alone), 6) time of home visits (antepartum and postpartum vs. postpartum only), and 7) publication year (<2008 vs. > 2008). Likewise, subgroup analysis was done for exclusive breastfeeding outcome which varied by, 1) number or frequency of PNC visits (<3 vs. $>3$ visits), 2$)$ coverage of $\mathrm{PNC}$ visits $(<70 \%$ vs. $>70 \%), 3$ ) duration of intervention or follow-up (<4 vs. $>4$ weeks), 4) age at exclusive breastfeeding (neonatal period vs. more than neonatal period), 5) type of health worker (health professionals vs. CHWs), and 6) publication year (<2008 vs. > 2008).

In subgroup analysis, we presented both randomeffects and fixed-effects model estimates to visualize the presence of small-study effects; however, due to substantial heterogeneity, we preferred to discuss the results acquired from random-effects model.

\section{Sensitivity analysis}

We conducted a sensitivity analysis excluding trials that evaluated the effect of home-based follow-up of neonates born at and recruited from hospitals, to determine the pooled estimate of trials with home-based neonatal care which had poor access to health facilities.

\section{Results}

\section{Description of studies}

The characteristics of included studies are given in Table 1 below. Fourteen articles (2 randomized controlled trials (RCT), 11 cluster-randomized trials, and 1 quasi-experimental studies) were included. All included trials were published from 1999 to 2017.

Most of the trials were conducted in predominantly rural districts that had poor infrastructure (poor roads, communications, education, and health services). However, three studies were conducted in urban [33] or peri-urban [36, 37] settings which were within a short distance to the countries' capital cities (Table 1).

Twelve trials recruited CHWs and three studies employed health professionals including midwives and nurses. Health workers were trained for about a week to make home visits to offer preventive and promotive newborn care services. Table 2 presents the intervention packages implemented in each trial. All trials conducted 
Table 1 Characteristics of included studies

\begin{tabular}{|c|c|c|c|c|c|c|}
\hline Study ID & Design & Setting & Participants & $\begin{array}{l}\text { Effective } \\
\text { sample size } \\
\text { (intervention/ } \\
\text { control) }\end{array}$ & Outcomes & Notes \\
\hline $\begin{array}{l}\text { Bang } 1999 \\
{[38]}\end{array}$ & Cluster RCT & $\begin{array}{l}\text { Gadchiroli district of India } \\
\text { which is about } 1000 \mathrm{~km} \\
\text { from the state capital, } \\
\text { Mumbai. It is } \\
\text { underdeveloped district, } \\
\text { with poor infrastructure } \\
\text { (poor roads, } \\
\text { communications, } \\
\text { education, and health } \\
\text { services) }\end{array}$ & $\begin{array}{l}\text { Newborns in } 39 \\
\text { intervention and } 47 \\
\text { control villages ( } 2869 \text { and } \\
3122 \text { newborns, } \\
\text { respectively) }\end{array}$ & $1209 / 1315$ & $\begin{array}{l}\text { Neonatal mortality, } \\
\text { stillbirth, perinatal } \\
\text { mortality, and cause of } \\
\text { neonatal death }\end{array}$ & \\
\hline $\begin{array}{l}\text { Baqui } 2016 \\
\text { [39] }\end{array}$ & Cluster RCT & $\begin{array}{l}\text { Beanibazar, Zakiganj and } \\
\text { Kanaighat subdistricts of } \\
\text { Sylhet division of } \\
\text { Bangladesh }\end{array}$ & $\begin{array}{l}\text { Newborns within the } \\
\text { general community of the } \\
\text { Sylhet district in rural } \\
\text { northeast Bangladesh } \\
\text { ( } 9630 \text { and } 9852 \text { newborns } \\
\text { in the intervention and } \\
\text { control groups, } \\
\text { respectively) }\end{array}$ & $380 / 389$ & $\begin{array}{l}\text { Neonatal mortality and } \\
\text { cause-specific neonatal } \\
\text { mortality }\end{array}$ & \\
\hline $\begin{array}{l}\text { Bashour } \\
2008 \text { [33] }\end{array}$ & RCT & $\begin{array}{l}\text { A maternity teaching } \\
\text { hospital in Damascus, Syria }\end{array}$ & $\begin{array}{l}\text { A total of } 876 \text { women } \\
\text { were followed up in the } \\
\text { three study groups: group } \\
\text { A ( } 285 \text { women) } 4 \text { PNC } \\
\text { visit; group B ( } 294 \text { women) } \\
1 \text { PNC visit; and group C } \\
\text { ( } 297 \text { women) no visit } \\
\text { (control) }\end{array}$ & $\begin{array}{l}577 / 296 \text { for } \\
\text { NMR and } \\
498 / 258 \text { for } \\
\text { EBF outcome }\end{array}$ & $\begin{array}{l}\text { Maternal postpartum } \\
\text { morbidities; postnatal care } \\
\text { uptake; contraceptive } \\
\text { uptake and type; infant } \\
\text { morbidities; infant } \\
\text { immunization at three } \\
\text { months; and exclusive } \\
\text { breastfeeding during the } \\
\text { first four months of life. }\end{array}$ & \\
\hline $\begin{array}{l}\text { Bhandari } \\
2012 \text { [44] }\end{array}$ & Cluster RCT & $\begin{array}{l}\text { The trial was conducted in } \\
\text { communities with a } \\
\text { population of } 1.1 \text { million } \\
\text { served by } 18 \text { primary } \\
\text { health centers in the } \\
\text { district of Faridabad, } \\
\text { Haryana, India }\end{array}$ & $\begin{array}{l}29,667 \text { and } 30,813 \\
\text { newborns in intervention } \\
\text { and control clusters, } \\
\text { respectively }\end{array}$ & $\begin{array}{l}\text { 29,667/30, } \\
813 \text { for NMR } \\
\text { and } 6204 / \\
6163 \text { for EBF } \\
\text { outcome }\end{array}$ & $\begin{array}{l}\text { Neonatal and infant } \\
\text { mortality; newborn care } \\
\text { practices, exclusive } \\
\text { breastfeeding at } 4 \text { weeks }\end{array}$ & \\
\hline $\begin{array}{l}\text { Coutinho } \\
2005[37]\end{array}$ & RCT & $\begin{array}{l}\text { Urban areas of Palmares } \\
\text { and three neighboring } \\
\text { small towns (Catende, } \\
\text { Água Preta, and Joaquim } \\
\text { Nabuco) in the interior of } \\
\text { the State of Pernambuco, } \\
\text { northeastern Brazil). The } \\
\text { area is hilly and lies } 130 \mathrm{~km} \\
\text { southwest of Recife, the } \\
\text { State capital. }\end{array}$ & $\begin{array}{l}175 \text { control and } 175 \\
\text { intervention mother and } \\
\text { their newborn/infants }\end{array}$ & $175 / 175$ & $\begin{array}{l}\text { Rates of exclusive } \\
\text { breastfeeding at } 12 \text { weeks } \\
\text { of age over } 24 \mathrm{~h} \text { recall and } \\
\text { breastfeeding practices }\end{array}$ & $\begin{array}{l}\text { Compared the } \\
\text { hospital-based } \\
\text { intervention with a } \\
\text { combined } \\
\text { hospital-based and } \\
\text { community-based }\end{array}$ \\
\hline $\begin{array}{l}\text { Darmstadt } \\
2010[45]\end{array}$ & Cluster RCT & $\begin{array}{l}\text { The trial was implemented } \\
\text { in Mirzapur, a sub-district } \\
\text { of Tangail district, Dhaka } \\
\text { Division, Bangladesh, lo- } \\
\text { cated } 2 \mathrm{~h} \text { by car from the } \\
\text { capital city of Dhaka }\end{array}$ & $\begin{array}{l}4616 \text { and } 5241 \text { live births } \\
\text { were recorded from } 9987 \\
\text { and } 11,153 \text { participants in } \\
\text { the comparison and } \\
\text { intervention arm }\end{array}$ & $301 / 265$ & $\begin{array}{l}\text { Antenatal and immediate } \\
\text { newborn care behaviors, } \\
\text { knowledge of danger } \\
\text { signs, care-seeking for neo- } \\
\text { natal complications, and } \\
\text { neonatal mortality. }\end{array}$ & \\
\hline $\begin{array}{l}\text { Kirkwood } \\
2013 \text { [29] }\end{array}$ & Cluster RCT & $\begin{array}{l}\text { Undertaken in seven } \\
\text { predominantly rural } \\
\text { districts in the Brong Ahafo } \\
\text { Region, Ghana: Kintampo } \\
\text { North, Kintampo South, } \\
\text { Nkoranza North, Nkoranza } \\
\text { South, Tain, Techiman, and } \\
\text { Wench }\end{array}$ & $\begin{array}{l}11,419 \text { and } 11,144 \\
\text { newborn and mothers in } \\
\text { intervention and control } \\
\text { groups, respectively }\end{array}$ & $\begin{array}{l}11,419 / 11, \\
144 \text { for NMR } \\
\text { and } 1414 / \\
1371 \text { for EBF } \\
\text { outcome }\end{array}$ & $\begin{array}{l}\text { Neonatal mortality rate } \\
\text { and coverage of key } \\
\text { essential newborn-care } \\
\text { practices; exclusive breast- } \\
\text { feeding in the previous } 24 \\
\text { h between days } 26 \text { to } 32 \\
\text { after birth }\end{array}$ & $\begin{array}{l}\text { Same study area } \\
\text { with "Pitt } 2016 \text { " }\end{array}$ \\
\hline $\begin{array}{l}\text { Kumar } \\
2008 \text { [27] }\end{array}$ & Cluster RCT & $\begin{array}{l}\text { Shivgarh, a rural block in } \\
\text { Uttar Pradesh, with a } \\
\text { population of } 104,123 \text {. }\end{array}$ & $\begin{array}{l}1522 \text { intervention and } \\
1079 \text { control groups of } \\
\text { mothers and newborn in }\end{array}$ & $1522 / 1079$ & $\begin{array}{l}\text { Changes in newborn care } \\
\text { practices and neonatal } \\
\text { mortality rate compared }\end{array}$ & \\
\hline
\end{tabular}


Table 1 Characteristics of included studies (Continued)

\begin{tabular}{|c|c|c|c|c|c|c|}
\hline Study ID & Design & Setting & Participants & $\begin{array}{l}\text { Effective } \\
\text { sample size } \\
\text { (intervention/ } \\
\text { control) }\end{array}$ & Outcomes & Notes \\
\hline & & $\begin{array}{l}\text { Socioeconomic indicators } \\
\text { are among the lowest in } \\
\text { the state. }\end{array}$ & Shivgarh & & with the control group & \\
\hline $\begin{array}{l}\text { LeFevre } \\
2013 \text { [40] }\end{array}$ & Cluster RCT & $\begin{array}{l}\text { Beanibazar, Zakiganj and } \\
\text { Kanaighat subdistricts of } \\
\text { Sylhet division; a division } \\
\text { which has a higher level of } \\
\text { neonatal mortality and a } \\
\text { higher fertility rate than } \\
\text { any of the other five of } \\
\text { Bangladesh's divisions }\end{array}$ & $\begin{array}{l}364 \text { and } 750 \text { mothers and } \\
\text { newborns in intervention } \\
\text { and control groups, } \\
\text { respectively }\end{array}$ & $364 / 750$ & $\begin{array}{l}\text { Cost-effectiveness of two } \\
\text { strategies (home and } \\
\text { community care) for } \\
\text { neonatal and maternal } \\
\text { care }\end{array}$ & $\begin{array}{l}\text { Neonatal mortality } \\
\text { is reported in } \\
\text { "Baqui 2016". }\end{array}$ \\
\hline $\begin{array}{l}\text { Memon } \\
2015 \text { [41] }\end{array}$ & $\begin{array}{l}\text { quasi- } \\
\text { experimental }\end{array}$ & $\begin{array}{l}\text { Gilgit district which is } \\
\text { situated about } 600 \mathrm{~km} \\
\text { away from Islamabad, the } \\
\text { capital of Pakistan. The } \\
\text { population of district Gilgit } \\
\text { is around } 283,324 \text {, the } \\
\text { majority of which are } \\
\text { subsistence farmers. The } \\
\text { health infrastructure } \\
\text { comprised of three Basic } \\
\text { Health Units, one Rural } \\
\text { Health Centre, five Civil } \\
\text { Hospitals and one District } \\
\text { Head Quarter Hospital. }\end{array}$ & $\begin{array}{l}833 \text { and } 842 \text { mothers and } \\
\text { newborns in the } \\
\text { intervention and control } \\
\text { groups, respectively, in a } \\
\text { remote mountainous } \\
\text { district in Northern } \\
\text { Pakistan }\end{array}$ & $458 / 463$ & $\begin{array}{l}\text { Changes in maternal and } \\
\text { newborn care practices } \\
\text { and perinatal and neonatal } \\
\text { mortality rates }\end{array}$ & \\
\hline $\begin{array}{l}\text { Pitt } 2016 \\
{[43]}\end{array}$ & Cluster RCT & $\begin{array}{l}\text { Undertaken in seven } \\
\text { predominantly rural } \\
\text { districts in the Brong Ahafo } \\
\text { Region, Ghana: Kintampo } \\
\text { North, Kintampo South, } \\
\text { Nkoranza North, Nkoranza } \\
\text { South, Tain, Techiman, and } \\
\text { Wench }\end{array}$ & $\begin{array}{l}11,419 \text { mothers and their } \\
\text { newborns in intervention } \\
\text { and } 11,144 \text { Mothers and } \\
\text { their newborns in control } \\
\text { groups in seven districts of } \\
\text { rural Ghana }\end{array}$ & $\begin{array}{l}11,419 / 11 \\
144\end{array}$ & $\begin{array}{l}\text { Cost-effectiveness of home } \\
\text { visits to women and their } \\
\text { newborns for interventions } \\
\text { and cost per newborn } \\
\text { saved life. }\end{array}$ & $\begin{array}{l}\text { Neonatal mortality } \\
\text { is reported in } \\
\text { "Kirkwood 2013" }\end{array}$ \\
\hline $\begin{array}{l}\text { Soofi } 2017 \\
{[42]}\end{array}$ & Cluster RCT & $\begin{array}{l}\text { Naushahro Feroze district } \\
\text { of rural Sindh. The district } \\
\text { is located } 450 \mathrm{~km} \text { north of } \\
\text { Karachi with a population } \\
\text { of around } 1.3 \text { million }\end{array}$ & $\begin{array}{l}736 \text { mothers and } \\
\text { newborns in intervention } \\
\text { and } 1050 \text { mothers and } \\
\text { newborns in control } \\
\text { groups }\end{array}$ & $736 / 1050$ & $\begin{array}{l}\text { All-cause neonatal } \\
\text { mortality }\end{array}$ & \\
\hline $\begin{array}{l}\text { Tyllerskr } \\
2011[36]\end{array}$ & Cluster RCT & $\begin{array}{l}\text { The study was undertaken } \\
\text { in rural Banfora, southwest } \\
\text { Burkina Faso, Mbale } \\
\text { District, eastern Uganda, } \\
\text { and Paarl (a periurban site } \\
\text { close to Cape Town), } \\
\text { Umlazi (periurban site near } \\
\text { Durban), and Rietvlei (rural } \\
\text { Kwa Zulu Natal), South } \\
\text { Africa. }\end{array}$ & $\begin{array}{l}2579 \text { mother-infant pairs } \\
\text { to the intervention or con- } \\
\text { trol clusters }\end{array}$ & $1323 / 1256$ & $\begin{array}{l}\text { Prevalence of exclusive } \\
\text { breastfeeding and diarrhea } \\
\text { reported by mothers } \\
\text { regarding infants aged } 24 \\
\text { weeks over } 24 \mathrm{~h} \text { recall }\end{array}$ & \\
\hline $\begin{array}{l}\text { Waiswa } \\
2015 \text { [47] }\end{array}$ & Cluster RCT & $\begin{array}{l}\text { Iganga and Mayuge } \\
\text { districts in eastern Uganda, } \\
\text { within the lganga-Mayuge } \\
\text { Health and Demographic } \\
\text { Surveillance Site (HDSS). } \\
\text { The HDSS is predominately } \\
\text { rural, comprising } 65 \text { vil- } \\
\text { lages and a total popula- } \\
\text { tion of approximately } 70 \text {, } \\
000 \text {. }\end{array}$ & $\begin{array}{l}894 \text { and } 893 \text { mothers and } \\
\text { newborns in the } \\
\text { intervention and control } \\
\text { groups, respectively }\end{array}$ & $894 / 893$ & $\begin{array}{l}\text { Coverage of key essential } \\
\text { newborn care behaviors } \\
\text { (breastfeeding, thermal } \\
\text { care, and cord care); } \\
\text { exclusive breastfeeding } \\
\text { over neonatal period }\end{array}$ & $\begin{array}{l}\text { Health facility } \\
\text { strengthening was } \\
\text { done to improve } \\
\text { the quality of care } \\
\text { in all intervention } \\
\text { and control sites }\end{array}$ \\
\hline
\end{tabular}


Table 2 Descriptions of interventions

\begin{tabular}{|c|c|c|c|c|c|c|c|c|c|}
\hline Study ID & Interventions & Type of care & $\begin{array}{l}\text { Intervention } \\
\text { providers and } \\
\text { training }\end{array}$ & $\begin{array}{l}\text { Number } \\
\text { of ANC } \\
\text { visits }\end{array}$ & $\begin{array}{l}\text { Number } \\
\text { of PNC } \\
\text { visits }\end{array}$ & $\begin{array}{l}\text { Timing of } \\
\text { PNC visits }\end{array}$ & $\begin{array}{l}\text { Length of } \\
\text { postpartum } \\
\text { follow-up } \\
\text { (in weeks) }\end{array}$ & $\begin{array}{l}\text { Postpartum } \\
\text { visit } \\
\text { coverage } \\
(\%) \\
\end{array}$ & Comparator type \\
\hline $\begin{array}{l}\text { Bang } 1999 \\
{[38]}\end{array}$ & $\begin{array}{l}\text { Village women } \\
\text { health workers } \\
\text { were recruited } \\
\text { and trained to } \\
\text { provide health } \\
\text { education to } \\
\text { mothers and } \\
\text { treat sick } \\
\text { neonates }\end{array}$ & $\begin{array}{l}\text { Home visit } \\
\text { and } \\
\text { community } \\
\text { activities to } \\
\text { promote } \\
\text { optimal } \\
\text { neonatal } \\
\text { care } \\
\text { practices and } \\
\text { treatment of } \\
\text { sick neonates }\end{array}$ & $\begin{array}{l}\text { Women village } \\
\text { health workers } \\
\text { (5-10 grade) }\end{array}$ & 1 & 8 & $\begin{array}{l}\text { days } 1,2,3 \\
5,7,14,21 \\
28 \& \text { on any } \\
\text { other day if } \\
\text { the family } \\
\text { called }\end{array}$ & 4 & 84 & $\begin{array}{l}\text { Routine prenatal } \\
\text { care, } \\
\text { immunization, } \\
\text { family planning, } \\
\text { control of } \\
\text { communicable } \\
\text { diseases, and } \\
\text { curative medical } \\
\text { care were } \\
\text { provided in the } \\
\text { government } \\
\text { facilities }\end{array}$ \\
\hline $\begin{array}{l}\text { Baqui } 2016 \\
\text { [39] }\end{array}$ & $\begin{array}{l}\text { Both home care } \\
\text { and community } \\
\text { care maternal } \\
\text { and neonatal } \\
\text { health service } \\
\text { delivery } \\
\text { strategies by } \\
\text { Community } \\
\text { Health Workers } \\
\text { (CHWs); } \\
\text { community } \\
\text { mobilization and } \\
\text { behavior-change } \\
\text { communication } \\
\text { to promote birth } \\
\text { and newborn- } \\
\text { care practice }\end{array}$ & $\begin{array}{l}\text { Home visit } \\
\text { and } \\
\text { community } \\
\text { activities to } \\
\text { promote } \\
\text { optimal } \\
\text { neonatal } \\
\text { care } \\
\text { practices }\end{array}$ & $\begin{array}{l}\text { CHWs trained for } \\
5 \text { days }\end{array}$ & 2 & 3 & days $1,3 \& 7$ & 1 & 79 & $\begin{array}{l}\text { Active facility- } \\
\text { based } \\
\text { comparator }\end{array}$ \\
\hline $\begin{array}{l}\text { Bashour } \\
2008 \text { [33] }\end{array}$ & $\begin{array}{l}\text { Home visits to } \\
\text { examine and } \\
\text { counsel women }\end{array}$ & $\begin{array}{l}\text { Home visit } \\
\text { to promote } \\
\text { optimal } \\
\text { neonatal } \\
\text { care } \\
\text { practices }\end{array}$ & $\begin{array}{l}\text { Midwives trained } \\
\text { for } 5 \text { days }\end{array}$ & 0 & 5 & $\begin{array}{l}\text { Women in } \\
\text { group A } \\
\text { received } 4 \\
\text { home visits } \\
\text { on days 1,3, } \\
7, \& 30 \\
\text { women in } \\
\text { group B } \\
\text { received } 1 \\
\text { home visit } \\
\text { on day } 3\end{array}$ & 4 & 100 & $\begin{array}{l}\text { Usual hospital } \\
\text { care without } \\
\text { home visit in the } \\
\text { postpartum } \\
\text { period }\end{array}$ \\
\hline $\begin{array}{l}\text { Bhandari } \\
2012 \text { [44] }\end{array}$ & $\begin{array}{l}\text { Postnatal home } \\
\text { visits to promote } \\
\text { breastfeeding, } \\
\text { delaying bathing, } \\
\text { keeping the baby } \\
\text { warm, cord care, } \\
\text { care-seeking for } \\
\text { illness and } \\
\text { treated sick new- } \\
\text { borns and older } \\
\text { children }\end{array}$ & $\begin{array}{l}\text { Home visit } \\
\text { to promote } \\
\text { optimal } \\
\text { neonatal } \\
\text { care } \\
\text { practices and } \\
\text { treatment of } \\
\text { sick neonates }\end{array}$ & $\begin{array}{l}\text { CHWs, nurses, } \\
\text { and physicians } \\
\text { trained for } 11 \\
\text { days }\end{array}$ & 0 & 3 & days $1,3, \& 7$ & 6 & 90 & $\begin{array}{l}\text { Usual or routine } \\
\text { facility-based care }\end{array}$ \\
\hline $\begin{array}{l}\text { Coutinho } \\
2005[37]\end{array}$ & $\begin{array}{l}\text { Home visits by } \\
\text { women with } \\
\text { secondary school } \\
\text { education to } \\
\text { promote and } \\
\text { support exclusive } \\
\text { breastfeeding }\end{array}$ & $\begin{array}{l}\text { Promote } \\
\text { optimal } \\
\text { neonatal } \\
\text { care } \\
\text { practices }\end{array}$ & $\begin{array}{l}\text { Health care } \\
\text { providers, } \\
\text { midwives and } \\
\text { nursing } \\
\text { assistants trained } \\
\text { for } 20 \mathrm{~h}\end{array}$ & 0 & 10 & $\begin{array}{l}\text { days } 3,7,15, \\
\& 30 \text { and } \\
\text { every } 2 \\
\text { weeks during } \\
\text { the second } \\
\text { month, and } \\
\text { once a } \\
\text { month } \\
\text { during the } \\
3-6 \text { months }\end{array}$ & 24 & 83 & $\begin{array}{l}\text { Women's usual } \\
\text { stay facility } 24 \mathrm{~h} \\
\text { to } 48 \mathrm{~h} \text { after } \\
\text { deliveries. } \\
\text { Maternity staff } \\
\text { would counsel } \\
\text { and encourage } \\
\text { mothers to } \\
\text { initiate and } \\
\text { maintain } \\
\text { exclusive } \\
\text { breastfeeding }\end{array}$ \\
\hline
\end{tabular}


Table 2 Descriptions of interventions (Continued)

\begin{tabular}{|c|c|c|c|c|c|c|c|c|c|}
\hline Study ID & Interventions & Type of care & $\begin{array}{l}\text { Intervention } \\
\text { providers and } \\
\text { training }\end{array}$ & $\begin{array}{l}\text { Number } \\
\text { of ANC } \\
\text { visits }\end{array}$ & $\begin{array}{l}\text { Number } \\
\text { of PNC } \\
\text { visits }\end{array}$ & $\begin{array}{l}\text { Timing of } \\
\text { PNC visits }\end{array}$ & $\begin{array}{l}\text { Length of } \\
\text { postpartum } \\
\text { follow-up } \\
\text { (in weeks) }\end{array}$ & $\begin{array}{l}\text { Postpartum } \\
\text { visit } \\
\text { coverage } \\
(\%)\end{array}$ & Comparator type \\
\hline $\begin{array}{l}\text { Darmstadt } \\
2010 \text { [45] }\end{array}$ & $\begin{array}{l}\text {-Pregnancy } \\
\text { surveillance to } \\
\text { identify } \\
\text { pregnancies by } \\
\text { CHW } \\
\text {-Antepartum } \\
\text { home visits to } \\
\text { promote birth } \\
\text { and newborn } \\
\text { care } \\
\text { preparedness } \\
\text {-Postpartum } \\
\text { home visits to } \\
\text { promote } \\
\text { preventive care } \\
\text { practices and to } \\
\text { assess newborns } \\
\text { for illness, and } \\
\text { referred sick } \\
\text { neonates }\end{array}$ & $\begin{array}{l}\text { Home visit } \\
\text { to promote } \\
\text { optimal } \\
\text { neonatal } \\
\text { care } \\
\text { practices and } \\
\text { treatment of } \\
\text { sick neonates }\end{array}$ & $\begin{array}{l}\text { CHWs trained for } \\
36 \text { days on } \\
\text { pregnancy } \\
\text { surveillance, } \\
\text { negotiation skills, } \\
\text { essential } \\
\text { newborn care, } \\
\text { neonatal illness } \\
\text { surveillance and } \\
\text { management of } \\
\text { illness }\end{array}$ & 2 & 3 & $\begin{array}{l}\text { days } 1,2,5 \& \\
8\end{array}$ & 1 & 69 & $\begin{array}{l}\text { Usual health } \\
\text { services provided } \\
\text { by the } \\
\text { government, } \\
\text { non- } \\
\text { governmental or- } \\
\text { ganizations and } \\
\text { private providers }\end{array}$ \\
\hline $\begin{array}{l}\text { Kirkwood } \\
2013 \text { [29] }\end{array}$ & $\begin{array}{l}\text { Community- } \\
\text { based } \\
\text { surveillance } \\
\text { volunteers were } \\
\text { trained to } \\
\text { identify pregnant } \\
\text { women and to } \\
\text { make home visits } \\
\text { during } \\
\text { pregnancy and } \\
\text { postpartum to } \\
\text { promote } \\
\text { essential } \\
\text { newborn-care } \\
\text { practices, weigh } \\
\text { and assess babies } \\
\text { for danger signs, } \\
\text { and refer as ne- } \\
\text { cessary; } \\
\text { community-wide } \\
\text { meetings }\end{array}$ & $\begin{array}{l}\text { Home visit } \\
\text { and } \\
\text { community } \\
\text { activities to } \\
\text { promote } \\
\text { optimal } \\
\text { neonatal } \\
\text { care } \\
\text { practices }\end{array}$ & $\begin{array}{l}\text { community- } \\
\text { based } \\
\text { surveillance } \\
\text { volunteers } \\
\text { (CBSVs) (trained } \\
\text { for } 9 \text { days) }\end{array}$ & 2 & 3 & days $1,3, \& 7$ & 1 & 63 & $\begin{array}{l}\text { Routine maternal } \\
\text { and child health } \\
\text { care (ANC, facility } \\
\text { delivery, } \\
\text { postpartum } \\
\text { check-ups, infant } \\
\text { welfare). }\end{array}$ \\
\hline $\begin{array}{l}\text { Kumar } \\
2008 \text { [28] }\end{array}$ & $\begin{array}{l}\text { CHWs provided } \\
\text { preventive \& } \\
\text { promotive } \\
\text { package of } \\
\text { interventions for } \\
\text { essential } \\
\text { newborn care } \\
\text { (birth } \\
\text { preparedness, } \\
\text { clean delivery, } \\
\text { and cord care, } \\
\text { thermal care, } \\
\text { breastfeeding } \\
\text { promotion, and } \\
\text { danger sign } \\
\text { recognition); } \\
\text { community- } \\
\text { based interven- } \\
\text { tion for behavior } \\
\text { change } \\
\text { management }\end{array}$ & $\begin{array}{l}\text { Home visit } \\
\text { and } \\
\text { community } \\
\text { activities to } \\
\text { promote } \\
\text { optimal } \\
\text { neonatal } \\
\text { care } \\
\text { practices }\end{array}$ & CHWs & 2 & 2 & days $1 \& 3$ & 1 & 68 & $\begin{array}{l}\text { Usual services } \\
\text { (ANC, delivery, } \\
\text { PNC, and } \\
\text { vaccination } \\
\text { services) }\end{array}$ \\
\hline $\begin{array}{l}\text { LeFevre } \\
2013 \text { [40] }\end{array}$ & $\begin{array}{l}\text {-CHWs provided } \\
\text { an initial dose of }\end{array}$ & $\begin{array}{l}\text { Home visit } \\
\text { and }\end{array}$ & $\begin{array}{l}\text { CHWs } \\
\text { (secondary }\end{array}$ & 2 & 3 & days $1,3 \& 7$ & 1 & 79 & $\begin{array}{l}\text { Pre-existing level } \\
\text { of care }\end{array}$ \\
\hline
\end{tabular}


Table 2 Descriptions of interventions (Continued)

\begin{tabular}{|c|c|c|c|c|c|c|c|c|c|}
\hline Study ID & Interventions & Type of care & $\begin{array}{l}\text { Intervention } \\
\text { providers and } \\
\text { training }\end{array}$ & $\begin{array}{l}\text { Number } \\
\text { of ANC } \\
\text { visits }\end{array}$ & $\begin{array}{l}\text { Number } \\
\text { of PNC } \\
\text { visits }\end{array}$ & $\begin{array}{l}\text { Timing of } \\
\text { PNC visits }\end{array}$ & $\begin{array}{l}\text { Length of } \\
\text { postpartum } \\
\text { follow-up } \\
\text { (in weeks) }\end{array}$ & $\begin{array}{l}\text { Postpartum } \\
\text { visit } \\
\text { coverage } \\
(\%)\end{array}$ & Comparator type \\
\hline & $\begin{array}{l}\text { antibiotic } \\
\text { treatment to the } \\
\text { infant with } \\
\text { suspected severe } \\
\text { neonatal illness } \\
\text { and to promote } \\
\text { the referral } \\
\text {-Community } \\
\text { mobilization and } \\
\text { behavior-change } \\
\text { communication } \\
\text { to promote birth } \\
\text { and newborn- } \\
\text { care } \\
\text { preparedness }\end{array}$ & $\begin{array}{l}\text { community } \\
\text { activities to } \\
\text { promote } \\
\text { optimal } \\
\text { neonatal } \\
\text { care } \\
\text { practices and } \\
\text { treatment of } \\
\text { sick neonates }\end{array}$ & $\begin{array}{l}\text { school } \\
\text { education) } \\
\text { trained for } 5 \\
\text { days }\end{array}$ & & & & & & \\
\hline $\begin{array}{l}\text { Memon } \\
2015 \text { [41] }\end{array}$ & $\begin{array}{l}\text { Promotion of } \\
\text { ANC, nutrition, } \\
\text { skilled delivery, } \\
\text { and healthy } \\
\text { newborn care } \\
\text { practices; } \\
\text { community } \\
\text { mobilization and } \\
\text { awareness } \\
\text { creation }\end{array}$ & $\begin{array}{l}\text { Home visit } \\
\text { and } \\
\text { community } \\
\text { activities to } \\
\text { promote } \\
\text { optimal } \\
\text { neonatal } \\
\text { care } \\
\text { practices }\end{array}$ & $\begin{array}{l}\text { Lay health } \\
\text { workers (LHW)/ } \\
\text { CHWs; LHW, } \\
\text { local resident } \\
\text { women with } 8 \\
\text { grade of formal } \\
\text { education were } \\
\text { trained for } 18 \\
\text { months }\end{array}$ & 2 & 1 & Monthly & 1 & 83 & $\begin{array}{l}\text { Routine health } \\
\text { services }\end{array}$ \\
\hline $\begin{array}{l}\text { Pitt } 2016 \\
\text { [43] }\end{array}$ & $\begin{array}{l}\text { Antepartum and } \\
\text { postpartum } \\
\text { home visits to } \\
\text { promote } \\
\text { essential } \\
\text { newborn-care } \\
\text { practices and as- } \\
\text { sess babies for } \\
\text { danger signs, and } \\
\text { refer as neces- } \\
\text { sary); facilitated } \\
\text { community-wide } \\
\text { meetings }\end{array}$ & $\begin{array}{l}\text { Home visit } \\
\text { and } \\
\text { community } \\
\text { activities to } \\
\text { promote } \\
\text { optimal } \\
\text { neonatal } \\
\text { care } \\
\text { practices }\end{array}$ & $\begin{array}{l}\text { Community } \\
\text { volunteers }\end{array}$ & 2 & 3 & days $1,3, \& 7$ & 1 & 63 & $\begin{array}{l}\text { Routine maternal } \\
\text { and child health } \\
\text { care (ANC, facility } \\
\text { delivery, } \\
\text { postpartum } \\
\text { check-ups, infant } \\
\text { welfare) }\end{array}$ \\
\hline $\begin{array}{l}\text { Soofi } 2017 \\
{[42]}\end{array}$ & $\begin{array}{l}\text { Lady Health } \\
\text { Workers (LHW) } \\
\text { provided } \\
\text { community } \\
\text { mobilization and } \\
\text { education } \\
\text { package and } \\
\text { recognition of } \\
\text { possibly } \\
\text { asphyxiated } \\
\text { newborn infants } \\
\text { at birth and bag } \\
\text { and mask } \\
\text { resuscitation as } \\
\text { needed, and } \\
\text { recognition and } \\
\text { management of } \\
\text { suspected } \\
\text { neonatal } \\
\text { infections. }\end{array}$ & $\begin{array}{l}\text { Home visit } \\
\text { and } \\
\text { community } \\
\text { activities to } \\
\text { promote } \\
\text { optimal } \\
\text { neonatal } \\
\text { care } \\
\text { practices and } \\
\text { treatment of } \\
\text { sick neonates }\end{array}$ & $\begin{array}{l}\text { LHW received an } \\
\text { initial } 3 \text { days of } \\
\text { training and } \\
\text { monthly 1-day } \\
\text { refresher ses- } \\
\text { sions thereafter }\end{array}$ & 0 & 4 & $\begin{array}{l}\text { attend } \\
\text { deliveries } \\
\text { and days } 3,7 \text {, } \\
14, \& 28 \text { after } \\
\text { birth }\end{array}$ & 4 & 30 & $\begin{array}{l}\text {-LHW program } \\
\text { continued to } \\
\text { function as usual. } \\
\text {-They continued } \\
\text { to have regular } \\
\text { monthly } \\
\text { debriefing and } \\
\text { refresher training } \\
\text { according to the } \\
\text { standard national } \\
\text { LHW program }\end{array}$ \\
\hline $\begin{array}{l}\text { Tyllerskr } \\
2011 \text { [36] }\end{array}$ & $\begin{array}{l}\text { Trained peer } \\
\text { counselors made } \\
\text { antenatal and } \\
\text { postpartum } \\
\text { breastfeeding }\end{array}$ & $\begin{array}{l}\text { Home visit } \\
\text { to promote } \\
\text { optimal } \\
\text { neonatal } \\
\text { care }\end{array}$ & $\begin{array}{l}\text { Peer counselors } \\
\text { trained for } 1 \\
\text { week }\end{array}$ & 1 & 4 & $\begin{array}{l}\text {-In Burkina } \\
\text { Faso: home } \\
\text { visits at } \\
\text { weeks 1, 2, 4, } \\
8,16 \text {, and } 20\end{array}$ & 6 & 100 & $\begin{array}{l}\text {-Standard health } \\
\text { care only in } \\
\text { Burkina Faso and } \\
\text { Uganda } \\
\text {-Home visit by }\end{array}$ \\
\hline
\end{tabular}


Table 2 Descriptions of interventions (Continued)

\begin{tabular}{|c|c|c|c|c|c|c|c|c|c|}
\hline Study ID & Interventions & Type of care & $\begin{array}{l}\text { Intervention } \\
\text { providers and } \\
\text { training }\end{array}$ & $\begin{array}{l}\text { Number } \\
\text { of ANC } \\
\text { visits }\end{array}$ & $\begin{array}{l}\text { Number } \\
\text { of PNC } \\
\text { visits }\end{array}$ & $\begin{array}{l}\text { Timing of } \\
\text { PNC visits }\end{array}$ & $\begin{array}{l}\text { Length of } \\
\text { postpartum } \\
\text { follow-up } \\
\text { (in weeks) }\end{array}$ & $\begin{array}{l}\text { Postpartum } \\
\text { visit } \\
\text { coverage } \\
\text { (\%) }\end{array}$ & Comparator type \\
\hline & $\begin{array}{l}\text { peer counseling } \\
\text { visits }\end{array}$ & practices & & & & $\begin{array}{l}\text {-In Uganda } \\
\text { and South } \\
\text { Africa: home } \\
\text { visits at } \\
\text { weeks } 1,4,7 \text {, } \\
\text { and } 10\end{array}$ & & & $\begin{array}{l}\text { peer counselors } \\
\text { in South Africa, } \\
\text { with the same } \\
\text { schedule as in } \\
\text { the intervention } \\
\text { clusters, but } \\
\text { assisted families } \\
\text { in obtaining birth } \\
\text { certificates and } \\
\text { social welfare } \\
\text { grants }\end{array}$ \\
\hline $\begin{array}{l}\text { Waiswa } \\
2015 \text { [47] }\end{array}$ & $\begin{array}{l}\text { Villages volunteer } \\
\text { CHWs were } \\
\text { trained to } \\
\text { identify pregnant } \\
\text { women and } \\
\text { make home visits } \\
\text { to offer } \\
\text { preventive and } \\
\text { promotive care } \\
\text { and counseling, } \\
\text { with extra visits } \\
\text { for sick and small } \\
\text { newborns to } \\
\text { assess and refer }\end{array}$ & $\begin{array}{l}\text { Home visit } \\
\text { to promote } \\
\text { optimal } \\
\text { neonatal } \\
\text { care } \\
\text { practices }\end{array}$ & $\begin{array}{l}\text { CHWs trained for } \\
5 \text { days }\end{array}$ & 2 & 3 & $\begin{array}{l}\text { first week } \\
\text { after birth }\end{array}$ & 1 & 63 & $\begin{array}{l}\text { Standard health } \\
\text { services, in } \\
\text { addition to the } \\
\text { improved health } \\
\text { facilities }\end{array}$ \\
\hline
\end{tabular}

postpartum home visits to promote newborn care practices; 11 trials did both antepartum and postpartum home visits. Moreover, nine trials conducted community activities [28, 29, 38-43] in addition to home visits to promote newborn care practices. Five of the studies trained providers/CHWs to identify sick newborns, refer them to facilities, and if referral was not possible to treat sick newborns in addition to preventive and promotive newborn care services [38, 40, 42, 44, 45] (Table 2).

Regarding the implementation strength of the studies, defined here as frequency of home visits and coverage of visits, each trial had an average of 4 postpartum home visits and an average of 1 antepartum visit (usually at third trimester). Likewise, coverage of home visits, proportion of mothers and/or their newborns received postpartum home visit, ranged from 30 to $100 \%$ (median $79 \%$ ).

Studies' follow-up period ranged from 1 to 24 weeks postpartum and more than half of the studies $(53 \%, n=8)$ followed-up mothers and their newborns for one week after delivery. The exclusive breastfeeding outcome definition varied across studies; three trials [29, 37, 44] determined exclusive breastfeeding at neonatal age while others determined at 3 months [36], 4 months [33], or 6 months [46]. Three studies observed exclusive breastfeeding in the previous $24 \mathrm{~h}$ recall at 12 weeks of age [37], 24 weeks of age [36], and age between days 26 to 32 after birth [29] (Table 2).

\section{Risk of bias in included studies}

The risk of bias of included trials is presented in Fig. 2.

\section{Allocation Bias}

Most trials $(n=11 ; \%=79)$ included had low risk of random sequence generation bias $[28,29,36,37,39,40$, $42-45,47]$; three studies had high risk of random sequence generation bias $[33,38,41]$ and one trial had unclear risk of random sequence generation bias [47]. Except for one [41] all other studies had low risk of allocation concealment bias.

\section{Blinding}

Blinding of participant and personnel was adequate in 11 of the studies included [27, 28, 33, 36, 38, 41-43, 45, $47,48]$. Four studies had high risk, either performance or detection bias [33, 37, 41, 42] and six and seven studies had an unclear risk of performance bias [29, $39-41,43,44]$ and detection bias $[29,38-40,43,44$, 47], respectively.

\section{Incomplete outcome data and selective reporting}

One trial had high risk of reporting bias [33]. Most studies had low risk of attrition; however, one trial [37] had unclear risk of reporting bias.

\section{Other potential sources of Bias}

Other potential sources of bias including baseline imbalances were identified in two studies [33, 44]. Moreover, possible cluster-level time-varying unmeasured confounders including regional pregnancy leave and employment policy might bias the exclusive breastfeeding 


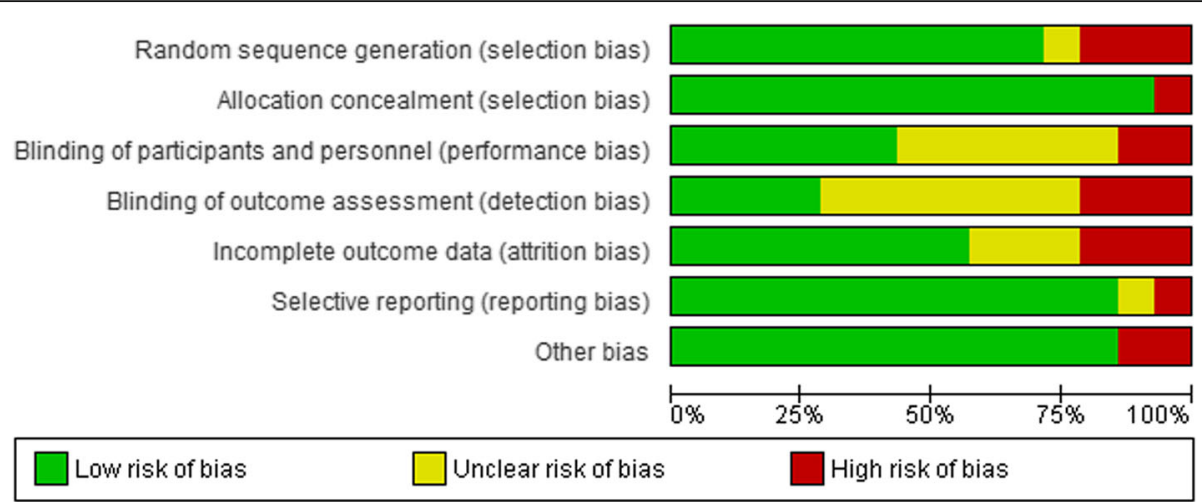

Fig. 2 Risk of bias graph: review authors' judgments about each risk of bias item presented as percentages across all included studies

outcome. However, there is no compelling reason to believe that these systematically influenced the intervention areas but not in the comparison areas unless otherwise, it happened after allocation of the treatment.

\section{Effects of interventions}

The Summary of Findings table gives estimates of the effects of home-based PNC on neonatal health outcomes as well as grading the level of evidence (Table 3).

\section{Neonatal mortality}

Nine studies $[28,29,33,38,39,41,42,44,45]$ involving 93,083 participants reported the effect of home visits on neonatal mortality as compared with the routine postpartum care. As presented in Fig. 3 below, the pooled analysis showed that home-based PNC reduced neonatal mortality by $24 \%$ (RR 0.76 , 95\% CI 0.62-0.92) with substantial heterogeneity between studies $\left(\mathrm{I}^{2}=69.0 \% ; p=<0.01 ; \mathrm{Tau}^{2}=0.0393\right)$.

\section{Sensitivity analysis}

Sensitivity analysis was conducted excluding trials that evaluated the effect of home-based follow-up of neonates born in and recruited from hospitals [33]. Following removal of this trial, the overall pooled estimate increased by only $1 \%$ (RR $0.75,95 \%$ CI $0.62-0.91$ ) with a slight increase in heterogeneity between studies $\left(\mathrm{I}^{2}=\right.$ $70.9 \% ; p=.001$ ) indicating no or little difference in the outcome and results were not driven by a trial that recruited newborns from hospitals.

\section{Subgroup analysis and meta-regression}

The subgroup analysis revealed that more than three PNC home visits contributed to reduction in neonatal mortality (RR: 0.70; 95\% CI: 0.53-0.91) than trials with less than three PNC home visits (RR: 0.77; 95\% CI: $0.61-0.98$; heterogeneity $p=.043$ ). Home visits by community health workers were associated with better survival of neonates (RR: 0.69 ; 95\% CI: 0.55-0.87) than visits by health professionals (RR: 1.26 ; 95\% CI: $0.37-4.30$; heterogeneity $P=.001$ ). Regarding intervention characteristics, community mobilization efforts with home visits to promote newborn care practices helped reduced neonatal mortality (RR: 0.69; 95\% CI: $0.54-0.88$ ) than home visits alone (RR: $0.97 ; 95 \% \mathrm{CI}$ : 0.90-1.05; heterogeneity $P=.001$ ). Moreover, trials with publication year 2008 and before revealed greater reduction in neonatal mortality (RR: $0.58 ; 95 \% \mathrm{CI}$ : 0.40-0.85) than publication year after 2008 (RR: 0.94; 95\% CI: $0.88-1.01$; heterogeneity $P<.01$ ).

Trials with coverage of home visits of $70 \%$ and above, showed non-statistically significant greater reduction in neonatal mortality (RR: 0.70; 95\% CI: 0.500.99 ) than trials with less than $70 \%$ coverage of home visits (RR: 0.87; 95\% CI: 0.76-1.00). Likewise, statistically non-significant trend towards a greater effect on mortality was observed with curative (inject-able antibiotics) and preventive interventions (RR: 0.82; 95\% CI: $0.63-1.05)$, as compared to only preventive intervention (RR: 0.70; 95\% CI: 0.48-1.03; heterogeneity $P=.016)($ Table 4$)$.

Table 3 Home-based postnatal care compared to routine PNC for newborn health

\begin{tabular}{|c|c|c|c|c|c|}
\hline \multirow[t]{2}{*}{ Outcomes } & \multicolumn{2}{|c|}{ Anticipated absolute effects (95\% Cl) } & \multirow{2}{*}{$\begin{array}{l}\text { Relative } \\
\text { effect(95\% } \\
\text { Cl) }\end{array}$} & \multirow{2}{*}{$\begin{array}{l}\text { № of } \\
\text { participants } \\
\text { (studies) }\end{array}$} & \multirow{2}{*}{$\begin{array}{l}\text { Certainty of the } \\
\text { evidence(GRADE }\end{array}$} \\
\hline & Risk with routine PNC & Risk with home-based PNC & & & \\
\hline Neonatal mortality & 42 per 1000 & $\begin{array}{l}32 \text { per } 1000 \\
(26-39)\end{array}$ & $\begin{array}{l}\text { RR 0.76 } \\
(0.62-0.92)\end{array}$ & $\begin{array}{c}93,083 \\
\text { (9 RCTs) }\end{array}$ & $\begin{array}{l}\oplus \oplus \oplus O \\
\text { MODERATE }\end{array}$ \\
\hline Exclusive breastfeeding & 424 per 1000 & $\begin{array}{l}680 \text { per } 1000 \\
(536-796)\end{array}$ & $\begin{array}{l}\text { OR 2.88 } \\
(1.57-5.29)\end{array}$ & $\begin{array}{c}20,624 \\
\text { (6 RCTs) }\end{array}$ & $\begin{array}{l}\oplus \oplus \oplus \oplus \\
\mathrm{HIGH}\end{array}$ \\
\hline
\end{tabular}




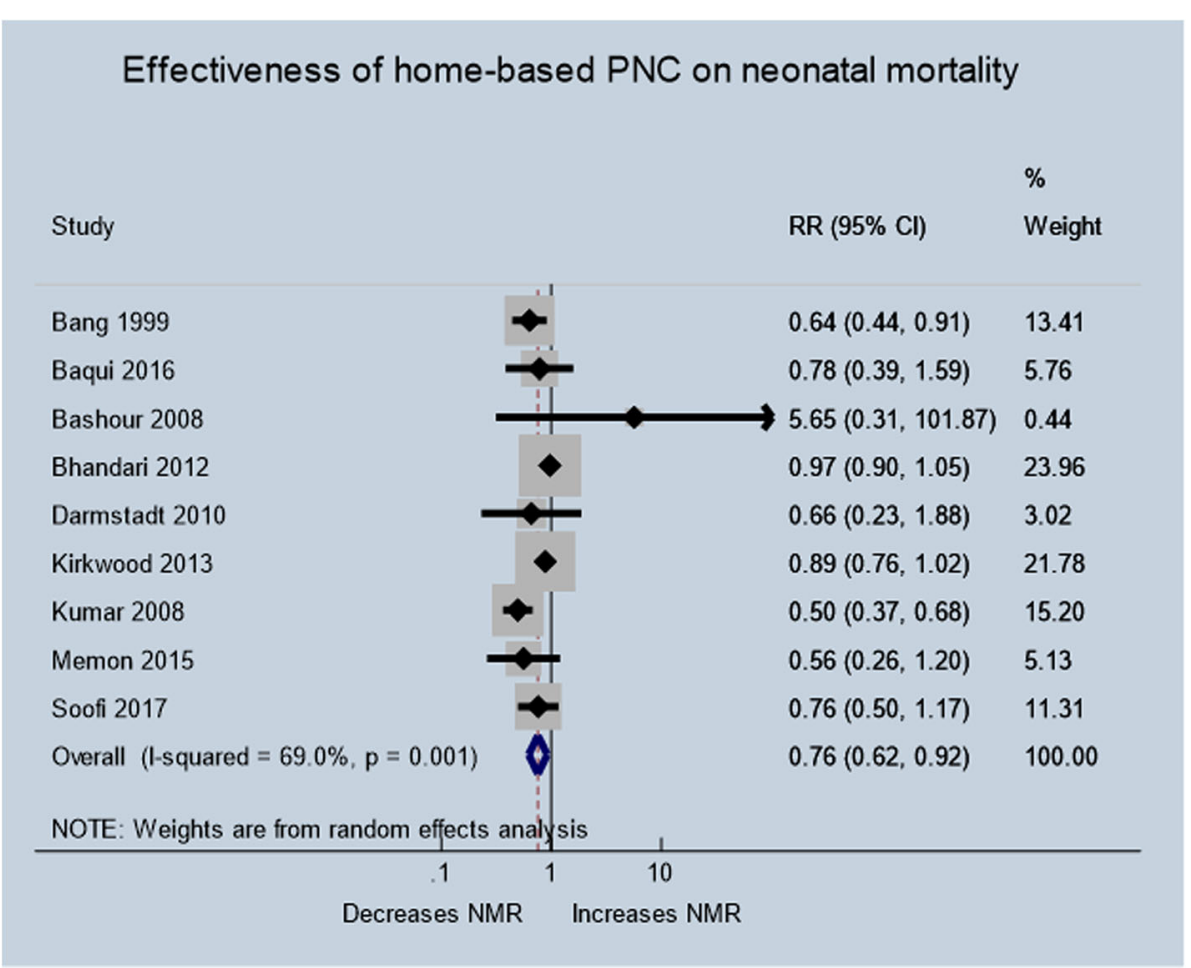

Fig. 3 Effectiveness of home-based postnatal care on neonatal mortality

In single-level meta-regression, only year of publication was significantly associated with neonatal mortality $(p=<.01)$. However, in multiple level meta-regression, no independent predictor variables were found (result not shown).

\section{Test of publication bias}

The funnel plot (Fig. 4) appeared symmetrical, which suggests no evidence of small-study effects. The Egger's test also indicated low possibility of publication bias (Coef. $=-1.263 ; p=.130)$.

\section{Exclusive breastfeeding}

Six trials [29, 33, 36, 37, 44, 47] involving 20,624 mothers reported on the exclusive breastfeeding outcome. The pooled analysis showed (Fig. 5) that the odds of exclusive breastfeeding practice of mothers in the home visit group were about three times higher than the routine care group [OR: 2.88; 95\% CI:1.57-5.29) with substantial heterogeneity between studies $\left(\mathrm{I}^{2}=98.2 \%\right.$; $\left.p=<.01 ; \mathrm{Tau}^{2}=0.5517\right)$.

\section{Subgroup analysis}

This outcome had substantial heterogeneity; as such, subgroup analysis was carried out. The subgroup analysis showed that groups of mothers who had more than $70 \%$ home visits (OR: 4.06; 95\% CI: 2.60-6.36) were exclusively breastfeeding significantly more than their counterparts (OR: 1.51; 95\% CI: 1.30-1.76). Likewise, groups of mothers who had more than four weeks of follow-up (OR: 5.69; 95\% CI: 5.29-6.12) were exclusively breastfeeding significantly more than their counterparts (OR: 2.94; 95\% CI: 0.91-9.50).

We found no significant difference among those mothers who had more than three visits (OR: 3.54; 95\% CI: 1.64-7.65) and those who had less or equal to three home visits (OR: 2.36; 95\% CI: 0.83-6.71). Though statistically non-significant, home visits by health professionals were associated with better exclusive breastfeeding practice (OR: 0.69 ; $95 \%$ CI: $2.60-8.69$ ) than visits by community health workers (OR: 2.25; 95\% CI: 1.01-5.29; heterogeneity $P<.01)$. Trials with publication year 2008 and before did not show significant difference in exclusive breastfeeding practice (OR: 2.94; 95\% CI: 0.91-9.50) than publication year after 2008 (OR: 2.86; 95\% CI: 1.36-6.04; heterogeneity $P<.01)$ (Table 5).

\section{Test of publication bias}

The funnel plot appeared symmetrical (result not shown). The Egger's test also indicated low possibility of publication bias (Coef. $=-7.870 ; p=.164$ ).

\section{Cost-effectiveness}

The cost-effectiveness results are presented in Table 6 below. Three trials reported the incremental cost for neonatal mortality outcomes. Different cost-effectiveness 
Table 4 Subgroup analysis for neonatal mortality outcome

\begin{tabular}{|c|c|c|c|c|c|c|c|c|}
\hline \multirow[t]{2}{*}{ Predictor variables } & \multirow{2}{*}{$\begin{array}{l}\text { \# of } \\
\text { trials }\end{array}$} & \multicolumn{2}{|c|}{ Random-effects model } & \multicolumn{2}{|c|}{ Fixed-effects model } & \multicolumn{2}{|c|}{ Test for heterogeneity } & \multirow{2}{*}{$\begin{array}{l}p \text {-value for } \\
\text { subgroup } \\
\text { heterogeneity }\end{array}$} \\
\hline & & $\mathrm{RR}$ & $95 \% \mathrm{Cl}$ & $\mathrm{RR}$ & $95 \% \mathrm{Cl}$ & $\overline{P^{2}(\%)}$ & $p$-value & \\
\hline Overall & 9 & 0.76 & $0.62-0.92$ & 0.91 & $0.85-0.97$ & 69.0 & $<0.01$ & NA \\
\hline \multicolumn{9}{|l|}{ Number of PNC visits } \\
\hline$>3$ & 4 & 0.70 & $0.53-0.91$ & 0.70 & $0.53-0.91$ & 0.0 & 0.485 & \multirow[t]{2}{*}{0.043} \\
\hline$<=3$ & 5 & 0.77 & $0.61-0.98$ & 0.92 & $0.86-0.98$ & 79.2 & $<0.01$ & \\
\hline \multicolumn{9}{|l|}{ Home visit coverage } \\
\hline More than $70 \%$ & 7 & 0.70 & $0.50-0.99$ & 0.92 & $0.85-0.99$ & 76.0 & $<0.01$ & \multirow[t]{2}{*}{0.511} \\
\hline Less than $70 \%$ & 2 & 0.87 & $0.76-1.00$ & 0.87 & $0.76-1.00$ & 0.0 & 0.517 & \\
\hline \multicolumn{9}{|l|}{ Type of provider } \\
\hline Healthcare provider & 2 & 1.26 & $0.37-4.30$ & 0.98 & $0.90-1.05$ & 29.5 & 0.234 & \multirow[t]{2}{*}{0.001} \\
\hline CHW & 7 & 0.69 & $0.55-0.87$ & 0.77 & $0.68-0.86$ & 52.8 & 0.048 & \\
\hline \multicolumn{9}{|l|}{ Intervention components } \\
\hline Community mobilization \& home visits & 6 & 0.69 & $0.54-0.88$ & 0.77 & $0.69-0.86$ & 60.5 & 0.027 & \multirow[t]{2}{*}{0.001} \\
\hline Home visits only & 3 & 0.97 & $0.90-1.05$ & 0.97 & $0.90-1.05$ & 0.0 & 0.377 & \\
\hline \multicolumn{9}{|l|}{ Type of care } \\
\hline Preventive & 4 & 0.70 & $0.48-1.03$ & 0.79 & $0.70-0.90$ & 0.70 & 0.010 & \multirow[t]{2}{*}{0.016} \\
\hline Preventive \& curative & 5 & 0.82 & $0.63-1.05$ & 0.95 & $0.88-1.02$ & 53.5 & 0.091 & \\
\hline \multicolumn{9}{|l|}{ Home visits } \\
\hline Antepartum \& postpartum & 6 & 0.67 & $0.51-0.88$ & 0.77 & $0.68-0.87$ & 60.7 & 0.026 & \multirow[t]{2}{*}{0.001} \\
\hline Postpartum only & 3 & 0.93 & $0.74-1.17$ & 0.97 & $0.90-1.04$ & 25.0 & 0.264 & \\
\hline \multicolumn{9}{|l|}{ Publication year } \\
\hline$<=2008$ & 3 & 0.58 & $0.40-0.85$ & 0.56 & $0.45-0.71$ & 43.9 & 0.168 & \multirow[t]{2}{*}{$<0.01$} \\
\hline$>2008$ & 6 & 0.94 & $0.88-1.01$ & 0.94 & $0.88-1.01$ & 0.0 & 0.430 & \\
\hline
\end{tabular}

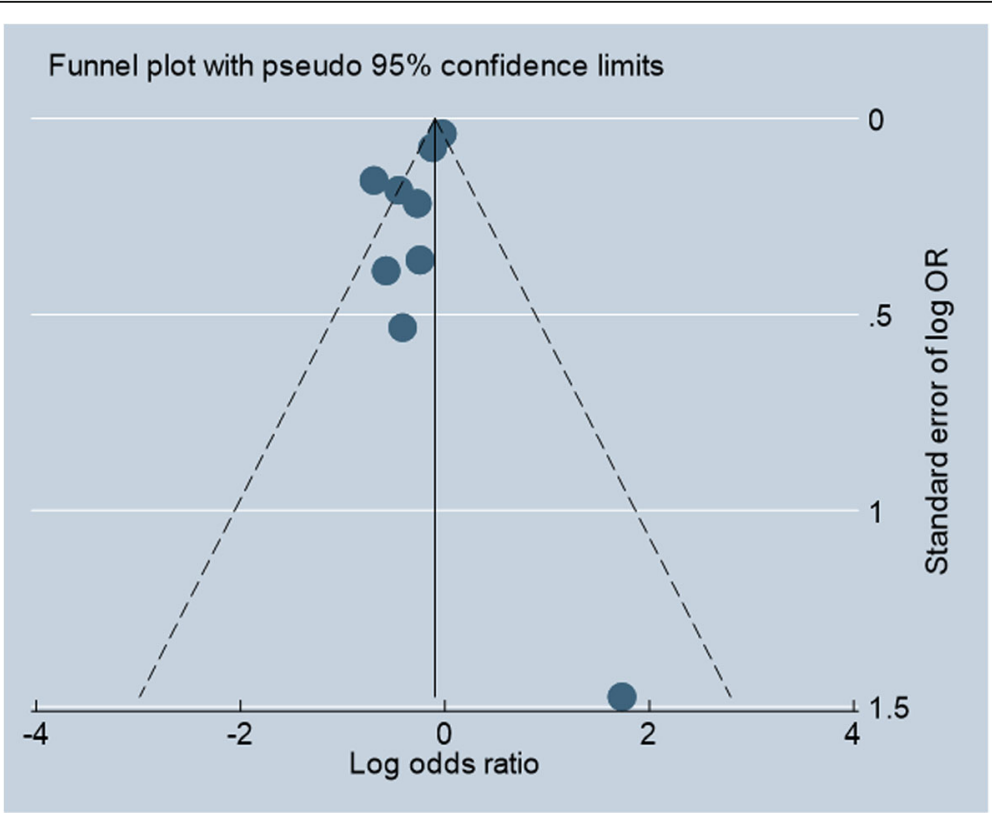

Fig. 4 Funnel plot for neonatal mortality outcome 


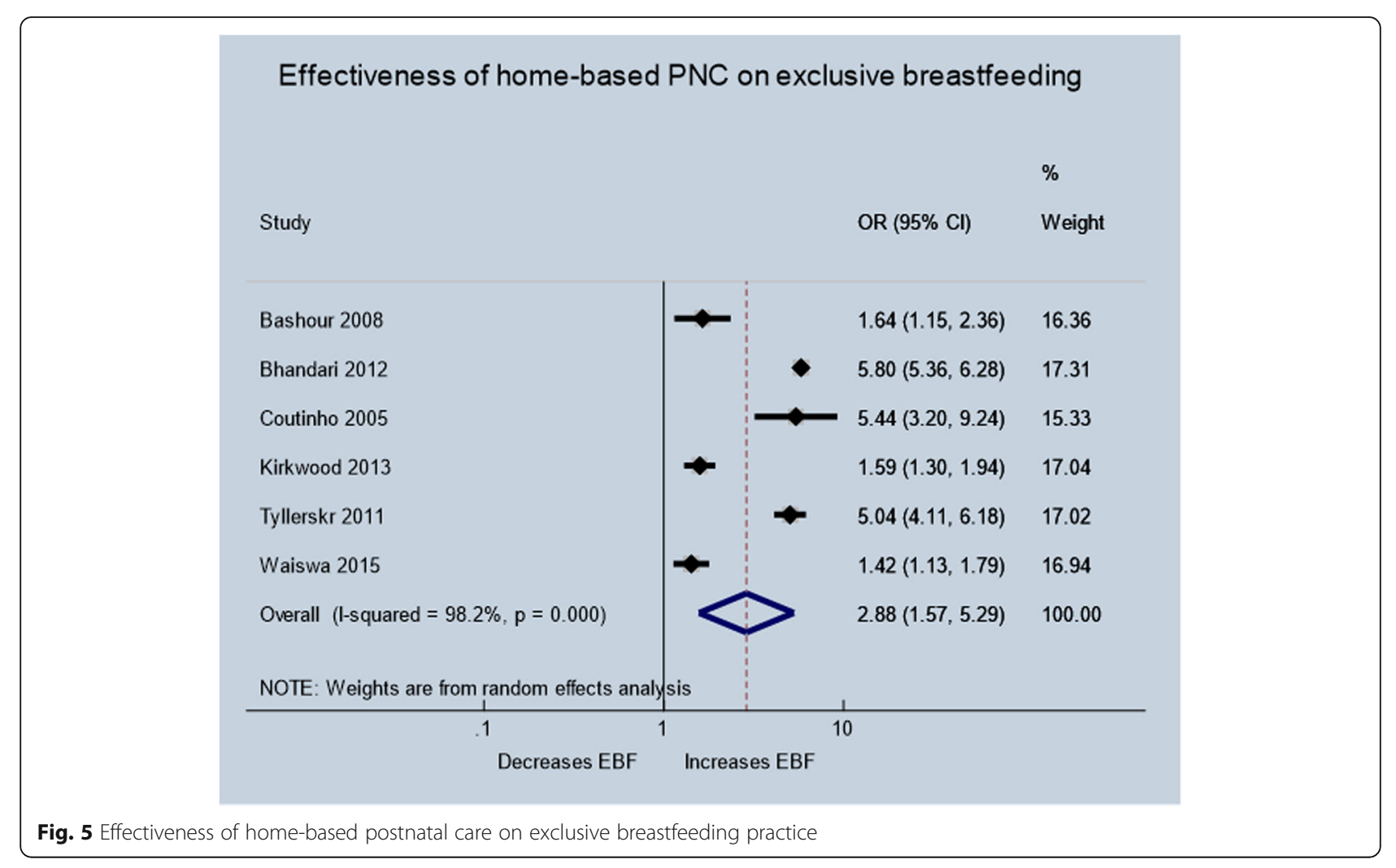

Table 5 Subgroup analysis in trials of home-based PNC visit on exclusive breastfeeding outcome

\begin{tabular}{|c|c|c|c|c|c|c|c|c|}
\hline \multirow[t]{2}{*}{ Predictor variables } & \multirow{2}{*}{$\begin{array}{l}\text { No. } \\
\text { of } \\
\text { trials }\end{array}$} & \multicolumn{2}{|c|}{ Random-effects model } & \multicolumn{2}{|c|}{ Fixed-effects model } & \multicolumn{2}{|c|}{ Test for heterogeneity } & \multirow{2}{*}{$\begin{array}{l}p \text {-value for } \\
\text { subgroup } \\
\text { heterogeneity }\end{array}$} \\
\hline & & $\overline{O R}$ & $95 \% \mathrm{Cl}$ & OR & $95 \% \mathrm{Cl}$ & $1^{2}(\%)$ & $p$-value & \\
\hline Overall & 6 & 2.88 & $1.57-5.29$ & 4.29 & $4.02-4.57$ & 98.2 & $<0.01$ & NA \\
\hline \multicolumn{9}{|l|}{ Number of PNC visits } \\
\hline$>3$ & 3 & 3.54 & $1.64-7.65$ & 3.89 & $3.36-4.71$ & 93.3 & $<0.01$ & 0.345 \\
\hline$<=3$ & 3 & 2.36 & $0.83-6.71$ & 4.34 & $4.05-4.66$ & 99.2 & $<0.01$ & \\
\hline \multicolumn{9}{|l|}{ Home visit coverage } \\
\hline$>70 \%$ & 4 & 4.06 & $2.60-6.36$ & 5.42 & $5.05-5.82$ & 93.4 & $<0.01$ & $<0.01$ \\
\hline$<=70 \%$ & 2 & 1.51 & $1.30-1.76$ & 1.51 & $1.30-1.76$ & 0.0 & 0.483 & \\
\hline \multicolumn{9}{|l|}{ Follow-up period } \\
\hline$>4$ weeks & 3 & 5.69 & $5.29-6.12$ & 5.69 & $5.29-6.12$ & 0.0 & $<0.01$ & $<0.01$ \\
\hline$<=4$ weeks & 3 & 1.53 & $1.33-1.76$ & 1.53 & $1.33-1.76$ & 0.0 & $<0.01$ & \\
\hline \multicolumn{9}{|c|}{ Age at exclusive breastfeeding } \\
\hline 1 month & 3 & 3.65 & $1.37-9.76$ & 4.88 & $4.54-5.25$ & 98.6 & $<0.01$ & $<0.01$ \\
\hline$>1$ month & 3 & 2.29 & $0.4-5.56$ & 2.64 & $2.30-3.04$ & 97.3 & $<0.01$ & \\
\hline \multicolumn{9}{|l|}{ Type of provider } \\
\hline Healthcare provider & 3 & 3.73 & $2.60-8.69$ & 5.47 & $5.07-5.91$ & 95.6 & $<0.01$ & $<0.01$ \\
\hline $\mathrm{CHW}$ & 3 & 2.25 & $1.01-5.29$ & 2.31 & $2.05-2.61$ & 97.7 & $<0.01$ & \\
\hline \multicolumn{9}{|l|}{ Publication year } \\
\hline$<=2008$ & 2 & 2.94 & $0.91-9.50$ & 2.40 & $1.78-3.23$ & 92.5 & $<0.01$ & $<0.01$ \\
\hline$>2008$ & 4 & 2.86 & $1.36-6.04$ & 4.41 & $4.13-4.71$ & 98.8 & $<0.01$ & \\
\hline
\end{tabular}


Table 6 Cost-effectiveness results

\begin{tabular}{|c|c|c|c|c|c|c|c|c|c|}
\hline \multirow[t]{2}{*}{ Study } & \multirow[t]{2}{*}{ Country } & \multirow[t]{2}{*}{ Intervention } & \multirow[t]{2}{*}{ Analytic view point } & \multirow[t]{2}{*}{ Quality } & \multirow{2}{*}{$\begin{array}{l}\text { Cost- } \\
\text { effectiveness } \\
\text { measure }\end{array}$} & \multirow{2}{*}{$\begin{array}{l}\text { Cost- } \\
\text { effectiveness } \\
\text { result } \\
\text { (US\$2016) }\end{array}$} & \multirow{2}{*}{$\begin{array}{l}\text { GDP } \\
\text { per } \\
\text { capita }\end{array}$} & \multicolumn{2}{|c|}{$\begin{array}{l}\text { Neonatal Mortality } \\
\text { Rate }\end{array}$} \\
\hline & & & & & & & & $\begin{array}{l}\text { Protective } \\
\text { Effectiveness } \\
(\%)\end{array}$ & $\begin{array}{l}\text { Control } \\
\text { group }\end{array}$ \\
\hline $\begin{array}{l}\text { Bang } \\
1999 \\
{[38]}\end{array}$ & India & $\begin{array}{l}\text { Home-based neonatal care by } \\
\text { village health workers }\end{array}$ & Program & Low & $\begin{array}{l}\text { per neonatal } \\
\text { death } \\
\text { averted }\end{array}$ & 13.86 & 1940 & 36.0 & 58.6 \\
\hline $\begin{array}{l}\text { Pitt } \\
2016 \\
{[43]}\end{array}$ & Ghana & $\begin{array}{l}\text { Home visits made to pregnant } \\
\text { women and their babies in the } \\
\text { first week of life by community- } \\
\text { based surveillance volunteers }\end{array}$ & $\begin{array}{l}\text { Provider } \\
\text { perspective }\end{array}$ & High & $\begin{array}{l}\text { per } \\
\text { discounted } \\
\text { life-year } \\
\text { saved }\end{array}$ & 319 & 1641 & 11.0 & 32.8 \\
\hline \multirow[t]{2}{*}{$\begin{array}{l}\text { LeFevre } \\
2013 \\
{[40]}\end{array}$} & \multirow[t]{2}{*}{ Bangladesh } & \multirow[t]{2}{*}{$\begin{array}{l}\text { Home visit made by community } \\
\text { health workers to offer MNH } \\
\text { services including postnatal } \\
\text { home visits }\end{array}$} & \multirow[t]{2}{*}{$\begin{array}{l}\text { Societal } \\
\text { perspective } \\
\text { (included program, } \\
\text { provider and } \\
\text { household costs) }\end{array}$} & High & $\begin{array}{l}\text { Cost per } \\
\text { neonatal } \\
\text { death } \\
\text { averted }\end{array}$ & 2939 & \multirow[t]{2}{*}{1517} & \multirow[t]{2}{*}{22.0} & \multirow[t]{2}{*}{43.7} \\
\hline & & & & & $\begin{array}{l}\text { Cost per } \\
\text { DALY } \\
\text { averted }\end{array}$ & 103.44 & & & \\
\hline
\end{tabular}

and cost-utility measures were used. All three trials reported cost per neonatal death averted [40, 38, 43] or newborn life-year saved [40, 43]. One trial used costutility measures (i.e., cost per DALYs gained) [40].

According to World Health Organization's Choosing Interventions that are Cost-Effective project (WHO-CHOICE) recommendations [49], considering cost per neonatal death averted, newborn life-year saved, and DALY averted measures, home-based neonatal care strategies were found to be cost-effective.

\section{Discussions}

The objective of this study was to systematically review the existing body of knowledge that explores the effectiveness and cost-effectiveness of home-based postpartum care on neonatal mortality and exclusive breastfeeding practice in LMICs.

The pooled analysis showed that home-based postpartum care is effective in reducing neonatal mortality and promoting exclusive breastfeeding practice in LMICs which have poor access to health care. Though on metaregression, no variable emerged as a significant predictor of an effect on neonatal mortality; the subgroup analysis suggested that more frequent postpartum home visits, combined community mobilization efforts with home visits, and interventions implemented prior to 2008 publication year, to had a greater reduction in neonatal mortality than their counterparts. Likewise, higher home visits may have encouraged more women to exclusively breastfeed.

The trials included in this review implemented a package of interventions that varied in intensity, components of interventions, duration of follow-up, and intervention provider. Some trials implemented both antepartum and postpartum home visits and other trials implemented postpartum home visits alone. Others included community mobilization efforts in addition to home-based promotion of newborn care practices. There were trials that included curative and preventive interventions, while others implemented preventive newborn care practices alone. Moreover, for breastfeeding outcome, there were variations in settings-some trials were conducted in predominantly in rural and others in peri-urban settings - as well as variations in how outcomes were measured and when-some trials determined exclusive breastfeeding at neonatal age while others determined at 3 , 4, or 6 months. As such, due to the complex nature of the interventions, it was difficult to differentiate the independent effects of different components of interventions on neonatal mortality.

Our findings augment the WHO recommendations of home-based postpartum care strategy [19]. The findings are also in line with previous systematic reviews that report home-visit strategy as effective in reducing neonatal mortality [11]; cost-effective [15]; and promote the practice of exclusive breastfeeding [50].

Most of the trials were of acceptable quality with low or unknown risk of bias, except for the two trials where the possibility of bias was high-one trial [33] which used block randomization based on estimated number of hospital deliveries per day and had significant baseline imbalances and the other trial [41] which was quasiexperimental. We graded the quality of the evidence using the GRADE approach; the evidence was graded as moderate for neonatal mortality outcome (Table 3, above), with downgrading decisions due to risks of bias and imprecision of effects, and high for exclusive breastfeeding.

This review provides several lessons for implementers of $\mathrm{MNH}$ programs in LMICs like Ethiopia. First, lower- 
and middle-income countries have shortage of trained health care providers [51-53] as well as inequitable distribution of providers $[54,55]$ which makes it difficult to intensify $\mathrm{MNH}$ care practices at facility level. This review illustrates that home-based $\mathrm{MNH}$ care can be practiced by community members through short term training on the packages needed to implement. Second, providing home-based $\mathrm{MNH}$ care might enable the implementers to access hard-to-reach areas, because people in LMICs have lower health-seeking behavior and they are far from health facilities.

In this review, we incorporated relevant subgroup and meta-regression analyses, explored any unit of analysis errors in the cluster randomized trials and appropriately combined all cluster- and individual-randomized trials together and no evidence of publication bias was found.

However, the review has limitations. First, there are high levels of unexplained heterogeneity. Second, in many countries, postpartum care is not clearly defined in national guidelines and standards [9]. This might create variability in the control group defining facility-level routine postpartum care. Third, the estimates of cost and resource used which are sensitive to variability across settings which might limit the generalizability and transferability of cost-effectiveness results beyond the study settings. Fourth, included studies used different cost-effectiveness and cost-utility measures as well as different analytic viewpoints which makes estimating the pooled estimate difficult. Finally, comparing costeffectiveness outcomes against GDP per capita as a threshold does not necessarily ensure that the strategy is affordable.

Well-designed evaluation of such interventions is required to establish the effectiveness of different intervention packages as well as to formulate the optimal packages and optimal timing of home visits and specific responsibilities of community health workers. Analytic viewpoint is one dimension that can affect study results. Large multi-center economic evaluation studies examining the impact of different analytic perspectives, implementation strength and willingness-to-pay parameters both in the intervention and comparison groups are required to understand well the degree to which strategies can be replicated elsewhere.

\section{Conclusions}

Home visits and community mobilization activities to promote optimal neonatal care practices by community health workers is associated with reduced neonatal mortality, increased practice of exclusive breastfeeding, and cost-effectiveness in improving newborn health outcomes for low-and-middle-income countries which have poor access to facility-based care. The subgroup analysis suggested that more than three PNC home visits, home visits by community health workers, community mobilization efforts with home visits, and interventions implemented prior to 2008 publication year to had better neonatal survival. Likewise, groups of mothers who received more home visit coverage and more weeks of follow-up were more exclusively breastfed their babies. The pooled estimates of outcome variables have high levels of unexplained heterogeneity so that results should be interpreted with caution. Furthermore, a well-designed evaluation study is warranted to formulate the optimal package of interventions for specific health cadres and optimal timing of home visits.

\section{Supplementary information}

Supplementary information accompanies this paper at https://doi.org/10. 1186/s12884-019-2651-6.

Additional file 1. Search Strategy.docx. This is a survey strategy used to search for articles from databases.

\section{Abbreviations}

CHW: Community health worker; $\mathrm{Cl}$ : Confidence interval; DALY: Disabilityadjusted-life-years; GDP: Gross domestic product; GRADE: Grading of recommendations assessment, development and evaluation; ICC: Inter-class correlation coefficient; ISPOR: International society for pharmacoeconomics and outcome research; LMICs: Low-and-middle-income countries; MNH: Maternal and newborn health; NHS: National health service; OR: Odds ratio; PICO: Population, intervention, comparison, and outcome;

PNC: Postnatal care; PRISMA: Preferred reporting items for systematic review and meta-Analysis; PROSPERO: International prospective register of systematic reviews; RCT: Randomized clinical trial; RevMan: Review manager; RR: Risk ratio; USD: US dollars; WHO: World health organization

\section{Acknowledgments}

The corresponding author would like to acknowledge Addis Continental Institute of Public Health (ACIPH) and University of Gondar (UoG) for giving me the opportunity to pursue my Ph.D. I take this opportunity to thank Prof. Yemane Berhane, Prof. Meaza Demissie, and my Ph.D. colleagues for their encouragement and joint learning. We would also like to acknowledge my colleague, Adey Abebe, for editing this manuscript.

\section{Authors' contributions}

GT and AW conceptualized the paper. GT and CB performed article search, data extraction, and data analysis. AW did interpretation and critical review. All authors contributed to the interpretation, commented on multiple versions, and approved the final manuscript.

\section{Funding}

The authors declare that they did not receive funding for this research from any source.

\section{Availability of data and materials}

The datasets used and/or analyzed during the current study are available from the corresponding author on reasonable request.

Ethics approval and consent to participate

Not applicable.

Consent for publication

Not applicable.

Competing interests

The authors declare that they have no competing interests. 


\section{Author details}

${ }^{1}$ The Last Ten Kilometers (L10K) Project, JSI Research \& Training Institute, Inc. Addis Ababa, Ethiopia. ${ }^{2}$ St. Paul Hospital Millennium Medical College, Birhan Health and Demographic Surveillance System, Addis Ababa, Ethiopia. ${ }^{3}$ Addis Ababa University School of Public Health, Addis Ababa, Ethiopia.

Received: 23 April 2019 Accepted: 29 November 2019

Published online: 18 December 2019

\section{References}

1. Lawn JE, Cousens S, Zupan J. 4 million neonatal deaths: when? Where? Why? Lancet 2005;365(9462):891-900. doi:https://doi.org/https://doi.org/10. 1016/S0140-6736(05)71048-5.

2. Bhutta ZA, Das JK, Bahl R, Lawn JE, Salam RA, Paul VK et al. Can available interventions end preventable deaths in mothers, newborn babies, and stillbirths, and at what cost? Lancet 2014;384(9940):347-370. doi:https://doi. org/https://doi.org/10.1016/S0140-6736(14)60792-3.

3. Adam T, Lim SS, Mehta S, Bhutta ZA, Fogstad H, Mathai M, et al. Cost effectiveness analysis of strategies for maternal and neonatal health in developing countries. Bmj. 2005;331(7525):1107.

4. Lassi ZS, Mallick D, Das JK, Mal L, Salam RA, Bhutta ZA. Essential interventions for child health. Reprod Health. 2014;11(1):S4.

5. WHO, UNICEF, UNFPA, World Bank Group, United Nations population division. Trends in maternal mortality: 1990 to 2015 population and development review. Geneva: World Health Organization; 2015.

6. Holmes W, Kennedy E. Reaching emergency obstetric care: overcoming the 'second delay'. Melbourne, Burnet Institute on behalf of Compass; 2010.

7. Darmstadt GL, Bhutta ZA, Cousens S, Adam T, Walker N, De Bernis L, et al. Evidence-based, cost-effective interventions: how many newborn babies can we save? Lancet. 2005;365(9463):977-88.

8. Belachew T, Taye A, Belachew T. Postnatal care service utilization and associated factors among mothers in Lemo Woreda, Ethiopia. J Women's Health Care. 2016;5(10.4172):2167-0420.1000318.

9. Warren C, Daly P, Toure L, Mongi P. Postnatal care. Opportunities for Africa's newborns Cape Town, South Africa: Partnership for Maternal, newborn and child. Health. 2006:79-90

10. Lain SJ, Roberts CL, Bowen JR, Nassar N. Early discharge of infants and risk of readmission for jaundice. Pediatrics. 2015;135(2):314. https://doi.org/10. 1542/peds.2014-2388.

11. Gogia S, Sachdev HS. Home visits by community health workers to prevent neonatal deaths in developing countries: a systematic review. Bull World Health Organ. 2010;88(9):658-66.

12. Lassi ZS. Bhutta ZA. The Cochrane Library: Community-based intervention packages for reducing maternal and neonatal morbidity and mortality and improving neonatal outcomes; 2015.

13. Marston C, Renedo A, McGowan C, Portela A. Effects of community participation on improving uptake of skilled care for maternal and newborn health: a systematic review. PLoS One. 2013:8(2):e55012.

14. Bath J, Wakerman J. Impact of community participation in primary health care: what is the evidence? Australian Journal of Primary Health. 2015;21(1):2-8.

15. Prost A, Colbourn T, Seward N, Azad K, Coomarasamy A, Copas A et al. Women's groups practising participatory learning and action to improve maternal and newborn health in low-resource settings: a systematic review and meta-analysis. Lancet 2013;381(9879):1736-1746. doi:https://doi.org/ https://doi.org/10.1016/S0140-6736(13)60685-6.

16. Bhutta ZA, Soofi S, Cousens S, Mohammad S, Memon ZA, Ali I et al. Improvement of perinatal and newborn care in rural Pakistan through community-based strategies: a cluster-randomised effectiveness trial. Lancet 2011;377(9763):403-412. doi:https:/doi.org/https:/doi.org/10.1016/S0140-6736(10)62274-X.

17. Bhutta ZA, Darmstadt GL, Hasan BS, Haws RA. Community-based interventions for improving perinatal and neonatal health outcomes in developing countries: a review of the evidence. Pediatr. 2005; 115(Supplement 2):519-617.

18. Mangham-Jefferies L, Pitt C, Cousens S, Mills A, Schellenberg J. Costeffectiveness of strategies to improve the utilization and provision of maternal and newborn health care in low-income and lower-middleincome countries: a systematic review. BMC Pregnancy Childbirth. 2014; 14(1):243.

19. WHO WHO recommendations on Postnatal care of the mother and newborn. www.who.int. Geneva: World Health Organization; 2014.
20. The World Bank. Official exchange rate (LCU per US\$, period average) International Monetary Fund, International Financial Statistics. World Bank, http://data.worldbank.org/indicator/PA.NUS.FCRF. 2017. Accessed 07/23/ 20182018.

21. The World Bank. GDP per capita (current US\$):World Bank national accounts data, and OECD National Accounts data files. World Bank, https://data. worldbank.org/indicator/NY.GDP.PCAP.CD. 2017. Accessed 07/30/2018 2018.

22. Mathewos B, Owen H, Sitrin D, Cousens S, Degefie T, Wall S, et al. Community-Based Interventions for Newborns in Ethiopia (COMBINE): Costeffectiveness analysis. Health Policy Plann. 2017;32(suppl_1):i21-32. https:// doi.org/10.1093/heapol/czx054

23. Higgins JP. Green S. Cochrane handbook for systematic reviews of interventions: John Wiley \& Sons; 2011

24. Cochrane T. Review manager (RevMan) 5.3. Copenhagen: The Nordic Cochrane Centre; 2008.

25. GRADEpro G. GRADEpro guideline development tool [software]. McMaster Univ. 2015:435.

26. Ramsey S, Willke R, Briggs A, Brown R, Buxton M, Chawla A, et al. Good research practices for cost-effectiveness analysis alongside clinical trials: the ISPOR RCT-CEA task force report. Value Health. 2005;8(5):521-33.

27. Kumar V, Kumar A, Das V, Srivastava NM, Baqui AH, Santosham M, et al. Community-driven impact of a newborn-focused behavioral intervention on maternal health in Shivgarh, India. Int J Gynecol Obstet. 2012;117(1):48-55.

28. Kumar V, Mohanty S, Kumar A, Misra RP, Santosham M, Awasthi S, et al. Effect of community-based behaviour change management on neonatal mortality in Shivgarh, Uttar Pradesh, India: a cluster-randomised controlled trial. Lancet. 2008;372(9644):1151-62.

29. Kirkwood BR, Manu A, ten Asbroek AH, Soremekun S, Weobong B, Gyan T, et al. Effect of the Newhints home-visits intervention on neonatal mortality rate and care practices in Ghana: a cluster randomised controlled trial. Lancet. 2013;381(9884):2184-92. https://doi.org/10.1016/s01406736(13)60095-1.

30. Hanson C, Manzi F, Mkumbo E, Shirima K, Penfold S, Hill Z, et al. Effectiveness of a home-based Counselling strategy on neonatal care and survival: a clusterrandomised trial in six districts of rural southern Tanzania. PLoS Med. 2015; 12(9):e1001881. https://doi.org/10.1371/journal.pmed.1001881.

31. Nair N, Tripathy P, Sachdev HS, Pradhan H, Bhattacharyya S, Gope R, et al. Effect of participatory women's groups and counselling through home visits on children's linear growth in rural eastern India (CARING trial): a clusterrandomised controlled trial. Lancet Glob Health. 2017;5(10):e1004-e16. https://doi.org/10.1016/s2214-109x(17)30339-x.

32. Manandhar DS, Osrin D, Shrestha BP, Mesko N, Morrison J, Tumbahangphe KM, et al. Effect of a participatory intervention with women's groups on birth outcomes in Nepal: cluster-randomised controlled trial. Lancet. 2004; 364(9438):970-9.

33. Bashour HN, Kharouf MH, AbdulSalam AA, El Asmar K, Tabbaa MA, Cheikha SA. Effect of postnatal home visits on maternal/infant outcomes in Syria: a randomized controlled trial. Public Health Nurs. 2008;25(2):115-25.

34. Sterne JA, Palmer TM. Meta-analysis in Stata: an updated collection from the Stata Journal. 2 ed. StataCorp LP; 2016.

35. StataCorp S. Statistical software: release 15.2017.

36. Tylleskar T, Jackson D, Meda N, Engebretsen IMS, Chopra M, Diallo AH, et al. Exclusive breastfeeding promotion by peer counsellors in sub-Saharan Africa (PROMISE-EBF): a cluster-randomised trial. Lancet. 2011;378(9789):420-7.

37. Coutinho SB, de Lira PIC, de Carvalho LM, Ashworth A. Comparison of the effect of two systems for the promotion of exclusive breastfeeding. Lancet. 2005;366(9491):1094-100. https://doi.org/10.1016/S0140-6736(05)67421-1.

38. Bang AT, Bang RA, Baitule SB, Reddy MH, Deshmukh MD. Effect of homebased neonatal care and management of sepsis on neonatal mortality: field trial in rural India. Lancet. 1999:354(9194):1955-61.

39. Baqui A, Williams E, El-Arifeen S, Applegate J, Mannan I, Begum N, et al. Effect of community-based newborn care on cause-specific neonatal mortality in Sylhet district, Bangladesh: findings of a cluster-randomized controlled trial. J Perinatol. 2016:36(1):71.

40. LeFevre AE, Shillcutt SD, Waters HR, Haider S, El Arifeen S, Mannan I, et al. Economic evaluation of neonatal care packages in a cluster-randomized controlled trial in Sylhet, Bangladesh. Bull World Health Organ. 2013;91(10):736-45.

41. Memon ZA, Khan GN, Soofi SB, Baig IY, Bhutta ZA. Impact of a community-based perinatal and newborn preventive care package on perinatal and neonatal mortality in a remote mountainous district in northern Pakistan. BMC Pregnancy Childbirth. 2015;15(1):106. https:/doi.org/10.1186/s12884-015-0538-8. 
42. Soofi S, Cousens S, Turab A, Wasan Y, Mohammed S, Ariff S, et al. Effect of provision of home-based curative health services by public sector healthcare providers on neonatal survival: a community-based cluster-randomised trial in rural Pakistan. Lancet Glob Health. 2017:5(8):e796-806. https://doi. org/10.1016/S2214-109X(17)30248-6.

43. Pitt C, Tawiah T, Soremekun S, ten Asbroek AHA, Manu A, TawiahAgyemang $C$ et al. Cost and cost-effectiveness of newborn home visits: findings from the Newhints cluster-randomised controlled trial in rural Ghana. Lancet Glob Health 2016;4(1):e45-e56. doi:https://doi.org/https://doi. org/10.1016/S2214-109X(15)00207-7.

44. Bhandari N, Mazumder S, Taneja S, Sommerfelt H, Strand TA. Effect of implementation of Integrated Management of Neonatal and Childhood Illness (IMNCl) programme on neonatal and infant mortality: cluster randomised controlled trial. BMJ (Clinical research ed). 2012;344:e1634. https://doi.org/10.1136/bmj.e1634.

45. Darmstadt GL, Choi Y, Arifeen SE, Bari S, Rahman SM, Mannan I, et al. Evaluation of a cluster-randomized controlled trial of a package of community-based maternal and newborn interventions in Mirzapur. Bangladesh PloS one. 2010;5(3):e9696.

46. Waiswa P, Manzi F, Mbaruku G, Rowe A, Marx M, Tomson G, et al. Effects of the EQUIP quasi-experimental study testing a collaborative quality improvement approach for maternal and newborn health care in Tanzania and Uganda. Implement Sci. 2017;12(1):89

47. Waiswa P, Pariyo G, Kallander K, Akuze J, Namazzi G, Ekirapa-Kiracho E, et al. Effect of the Uganda newborn study on care-seeking and care practices: a cluster-randomised controlled trial. Glob Health Action. 2015:8:24584. https://doi.org/10.3402/gha.v8.24584.

48. Fottrell E, Azad K, Kuddus A, Younes L, Shaha S, Nahar T, et al. The effect of increased coverage of participatory women's groups on neonatal mortality in Bangladesh: a cluster randomized trial. JAMA Pediatr. 2013;167(9):816-25.

49. Marseille E, Larson B, Kazi DS, Kahn JG, Rosen S. Thresholds for the costeffectiveness of interventions: alternative approaches. Bull World Health Organ. 2014;93:118-24.

50. Yonemoto N, Dowswell T, Nagai S, Mori R. Schedules for home visits in the early postpartum period. Evidence-based child health: a Cochrane review journal. 2014;9(1):5-99.

51. Kerber K, de Graft-Johnson JE, Bhutta ZA, Okong P, Starrs A, Lawn JE. Continuum of care for maternal, newborn, and child health: from slogan to service delivery. Lancet. 2007;370(9595):1358-69.

52. Munabi-Babigumira S, Glenton C, Lewin S, Fretheim A, Nabudere H. Factors that influence the provision of intrapartum and postnatal care by skilled birth attendants in low- and middle-income countries: a qualitative evidence synthesis. Cochrane Database Syst Rev. 2017;11:Cd011558. https:// doi.org/10.1002/14651858.CD011558.pub2.

53. Task Force on Health Systems Research. Informed choices for attaining the millennium development goals: towards an international cooperative agenda for health-systems research. Lancet 2004;364(9438):997-1003.

54. Gerein N, Green A, Pearson S. The implications of shortages of health professionals for maternal health in sub-Saharan Africa. Reproductive Health Matters. 2006;14(27):40-50. https://doi.org/10.1016/S0968-8080(06)27225-2.

55. Ahmed SM, Hossain MA, RajaChowdhury AM, Bhuiya AU. The health workforce crisis in Bangladesh: shortage, inappropriate skill-mix and inequitable distribution. Hum Resour Health. 2011;9(1):3. https://doi.org/10. 1186/1478-4491-9-3

\section{Publisher's Note}

Springer Nature remains neutral with regard to jurisdictional claims in published maps and institutional affiliations.

Ready to submit your research? Choose BMC and benefit from:

- fast, convenient online submission

- thorough peer review by experienced researchers in your field

- rapid publication on acceptance

- support for research data, including large and complex data types

- gold Open Access which fosters wider collaboration and increased citations

- maximum visibility for your research: over $100 \mathrm{M}$ website views per year

At $\mathrm{BMC}$, research is always in progress.

Learn more biomedcentral.com/submissions 